University of Louisville

ThinkIR: The University of Louisville's Institutional Repository

Electronic Theses and Dissertations

6-1946

\title{
A graphical solution for batch steam distillation of a binary mixture.
}

Howard D. Carlson 1921-

University of Louisville

Follow this and additional works at: https://ir.library.louisville.edu/etd

Part of the Chemical Engineering Commons

\section{Recommended Citation}

Carlson, Howard D. 1921-, "A graphical solution for batch steam distillation of a binary mixture." (1946). Electronic Theses and Dissertations. Paper 1875.

https://doi.org/10.18297/etd/1875

This Master's Thesis is brought to you for free and open access by ThinkIR: The University of Louisville's Institutional Repository. It has been accepted for inclusion in Electronic Theses and Dissertations by an authorized administrator of ThinkIR: The University of Louisville's Institutional Repository. This title appears here courtesy of the author, who has retained all other copyrights. For more information, please contact thinkir@louisville.edu. 
UNIVERSITY OF LOUISVIIEF

A GAPHICAI SOLUTIOH FOR BATCH STEAM DISTIIEATION OP A BIMARY MEXTUKE

\author{
A. Thesio \\ Submitted to the Faculty \\ of the Graduate school of the UnIrexeity of Louigvilie \\ In Partial Pulfiliment of the \\ Requirement: for the Degree

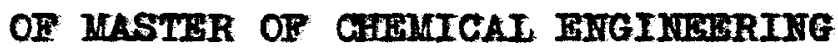

Department of Chentcel Bugineering

By

Howerd D. Carleon

Tear

1946 
A GRAPHICAI SOIUTION POR BATCH BMPAM DISTITTATION OF A BINARY MIXTURE

Howard D. CarIson

Approved by the Hxamining Committee Chas man Gordon C. Williams
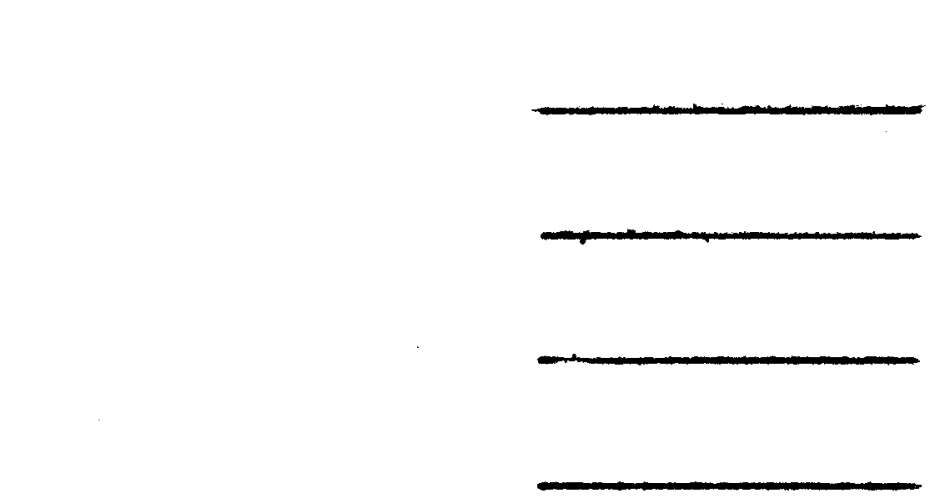

Date June 22,1946 
TABIE OF CONTHITS

Page

Iist of Pigures $-\ldots-\ldots$

IV

List of Tables $\ldots+\ldots$

$\nabla$

Ifst of SymboIs - - - - - - - - - - -

viti

Aclmowledgement $\ldots+\ldots$

$1 x$

Abetrmet - - - - - - - - - - - - -

$x$

Introduction $\ldots+\ldots$

1

Hietorieal - . - - - - - - - - -

3

Theoretical - . - . - . . - . - -

6

Bxperfmental - $-\ldots,-\ldots$

25

Discassion - - - - - - - - - - - -

Conclueions - $-\ldots, \ldots+\ldots$

Appendix - - - - - - - - - - - - -

51

Sumple Caloulations -,,---

52

Bibliogrepiry - $-+-\ldots$

82

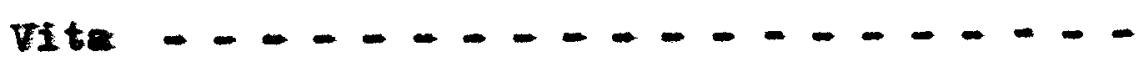

83 
IIST OF FIGURES

Page

Pigure 1 Vapor Pressure of Benzene and Bromobenzene vs. Mol Percent Benzene at Varfous Temperatures - $-\ldots+\ldots$

Figure 2 Vapor Pressure of Benzene and Toluene Fs.

MoI Percent Benzene et Varfous Temperatures

Plgure 3 Vapor Preseure of Benzene and Bromobenzene vo. Temperature at Constant MoI Percent Iines $-\ldots-+--_{-}-{ }_{-}$

Plgare 4 Vapor Preseure of Benzene and Toluene ve. Temperature at Constent Hol Percent IInes

Pigure 5 Derived $Y-X$ Curve for steam Dietiliation of Benzene-Bromobenzene Yixtures - - - -

Figure 6 Derived $Y-X$ Gurve for stean Distiliation of Bengene-Toluene Hixtures - -

Higure 7 Awdifary plot for Graphical Evaluation of $\int \frac{d x}{y-x}$ for Benzene-Brenabensene MIxtures -

Pigure 8 Awaliary Plot for Grapinical Evaluation of $\int \frac{d x}{y-x}$ for Benzene-Toluene Ifixtures - -

Figure 9 Relationship Between Composition and Volme of Dietillate for steam Dietillation of Benzene-Bromobenzene Mixtures - - - - 
Page

Figure 10 Relationship Between Composition and Volume

of Distliate for Steam Distillation of

Benzene-ToIuene Mixture日 - - - - - - 33

Figure 11 Index of Refraction va. Mol Parcent Bromo-

benzene for Benzene-Bromobenzene Mixtures - 34

Ftgure 12 Index of Refrection vs. Mol Percent Benzene

for Benzene-Poluene Mixtares - - - - - 35

Figure 13 specific Grevity ro. Index of Refraction

for Benzene-Bromobenzene Mixturee - - - 36

Fifure 14 Specific Grevity ro. Index of Refrection

for Benzene-Toluene Mixtures - - - - - 37

Figure 15 specific Eractiy v8. MoI Percent Bromo-

benzene for Benzene-Bromobenzene Hixtures - 38

Pigure 16 Specific Gravity - Yol Relationship for

Benzene-ToIuene MIxtures - - - - - 39

Figure 17 Sketch of Ixperimental Apparatus - - - - 40

Pigure 18 Temperature Correlation for Bengeno-Bromo-

benzene Ifxtures - - - - - - $--\ldots 1$

Plgure 19 Temperature Correlation for Benzene-goluene

Mixtures - - - - - - - - - $-\ldots 2$

Figure 20 Conversion Graph for Benzene-Browobenzene

Hixtures - - - - - - - - - - - 43

Pigure 21 Converaion Graph for Benzene-Polnene HAxtures 44 


\section{EIST OF TABIHS}

Page

Table I Vapor Pressure of Benzene, Bromobenzene, Toluene, and Watex at Varlous Temperatures $-\ldots-\ldots$ II

Table II Density of Benzene-Toluene Mixtures and Calculated Welght Percent r8. Mol Percent 12

TabIe III Experimental Data for Index of Refraction and Specific Gravity of Benzene-Bromobenzene Mixtures - $-\ldots$

Table IV Derived Data from Constructed Temperature Presiare Curve for Benzene, Bromobenzene. and Water $-\ldots+\ldots$

Table $V$ Foperimental Data for the Index of RefractIon re. Gomposition of Benzene-Taluene

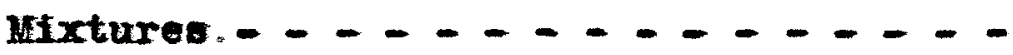

Tabie VI Experimental Data for Benzene-Bromobenzene Mxturea - Run Ho. 4 - - - - -

Table VII CaIculations for the Graphical Procedure using Benzene-Browobenzene ufxtures with a atarting compasition of 51 Mol Percent

Table VII Ixperimental Data for Benzene-Bromobenzene Ifxtures - Run Ko. 5 - - - - - - - 
Table IX Calculations far the Graphical Procedure using Benzene-Bromobenzene Mfxtares with a sarting Composition of $30 \mathrm{Mol}$ Percent

Table $x$ Experfmental Date for Benzene-Bromo-

benzene Hixtures - Run Ho. 6 - . . .

Table $X I$ Calculations for the Graphical Procedure using Benzene-Bromobenzene Mixtures with a eterting Composition of 70 Mol Percent

Table XII Derired Data from the Conetrueted Temperature Pressure Gurve for Benzene, Toluene, and Water $-\ldots$

Table XIII Experimental Data for Benzene-Toluene Mixtures - Run Ho. 7 - $-\ldots$

TabIe XIV Calculations for the Graphical Procedure using Benrene-Toluene Mixtures with a starting Composition of 48.8 Mol Percent 
LIST OF SYMBOLS

$I_{1}=$ Lols of original charge

$I_{2}=$ Hols of restausl charge

p = Partial rapor pregsure un. Hig.

$P_{0}=$ Vapor pressure m. Hg.

$\mathrm{T}=$ Temperature ${ }^{\circ} \mathrm{C}$

$x=$ Mol frection of $\mathrm{C}_{6} \mathrm{H}_{6}$ in liquid

$x_{1}=401$ fraction of $c_{6}{ }_{6} 6$ in original charge

$x_{2}=$ MoI fraction of $C_{6}{ }_{6} 6$ in restdual charge

$y=$ rol fraction of ${ }^{6} 6_{6}{ }^{H}$ in vepor 
A C K N

The author wienes to acknow-

Iedge the kind assigtance

and helprul suidance of

Dr. G. C. Wi1Iams.

who directed this

research. 


\begin{abstract}
The theory for the graphical solution of batch steam digtiliation of a binery mixture is presented and 11 Instrated. The results obtained from this sraphical procedure are compared with actual experimental results. The comparison showed rery close agreement between the graphical results and the experimentel results.

Three sete of experimental data are shown for benzene-bromobenzene mixtures and one complete set for benzene-toluene mixtures.
\end{abstract}


I N T R O D U C T I O N 
The trend in industry during the past few years has been to replace betch atean distillation equipment with continuous fractionating stills. However, there are many industrial applications which cannot be replaced by continuous fractionating installations. The purification of glycerine and fatty acids are examples of large scale operations of this latter Glass.

If a mixture of two Ilquids, each miscible with the other but both imisctble with water, is steam distilled, the composition of the distillate has not been determinable by direct calculations. such prablems in the past have only been solved by actually preforming a steam distillation experiment on the specific liquids involved. A graphical method has been suggested which might solve this problem for Iiquid mixtures which obey Raoults' Law. Infa graphical procedure would enable one to calculate the composition of the distillate at any given time during a batch steam distillation without actualiy resorting to experimental procedures. Hence, the purpose of this work was to determine the accuracy of this graphI cal procedure by comparing calculated results with actual experimental data wich was taken under controlled conditions. 
IIs 
Batch steam distillation is a very old process which has been developed over a long perfod of time. In 1904 Rayleigh (I) made a mathematical analysis of simple batch stean distillation and derived the equation which is now known as the Rayleigh Equation. In 1922 E. B. Kohman (2) dereloped an apparatus for batch steam distillation which was used to determine the amount of hydrogen sulfide erolved by foods when cooked at various temperatures. Nt about the same time $K$. Lewis and C. S. Robinson (3) intergrated the Rayleigh Equation for two liquids which have bolling points rery close togather. They derfred an equation based on the assumption that the ratio of the rapor pressures at one bolling temperature does not differ greatly from that at another boiling temperature. A fer years later in 1929 E. M. Baker and F. B. Pettibone (4) developed graphical method of determining the temperature of ateam distillation at various pressures using saturated steam. A partial pressure chart for steam digtillation was developed by C. A. Lee (5) in 1936 assuming that the temperature of the ateam was high enough so that no stean condensed in the still pot. Badger and McGabe (6) in 1936 and Naiker, Lewis, MaAdams and Gilliland (7) In 1937 presented the theory 
of batch steam distillation based on the Rayleigh Fquation. In $1941 \mathrm{~J}$. H. Perry (8) published the "Chemical Ingineers Hendbook" which included some unpublished notes of Hoddans who derived some equations for steam consumption in batch steam distillations. Op to the present time no attempt has been made to determine the composition of the distillate from the steam distillation of a binary solution when only the original conditions of the mixture and the desired amount of distillate has been fixed. 
I F IOREIICA 
The graphical method presented here was developed by G. C. WIIllams (9) on the asaumption that mixtures of the two 21quids may follow Raoults' Iaw. This Law states that the partial rapor pressure of the solvent in equilibrium with a solution is directly proportional to its mol fraction $x$, or

$$
p=x P_{0}
$$

where $p$ is the partial vapor pressure of the solvent and $P_{0}$ is the vapor pressure of the pure solvent at the ame temperature.

Data for the vapor pressure, specific gravity, and Index of refraction of benzene-bromobenzene can be found in Tables I, III and V. Conversion of weight percent to mol percent along with the density of benzene-toluene mixturea can be found in Table II. Tho rapor pressures are used to plot a partial pressure composition diagram shown in Pig. 1. At 100 Yol percent benzene the rapor pressure of pure benzene is plotted along the vertical axis. At 0 fol percent benzene or 100 Hol percent bromobenzene the rapor pressure of pure bromobenzene is plotted along the vertical axis. A straight line is dram between the rapor pressure of pare benzene and the rapor pressure of pure bromobenzene each at the same temperature. This line represents the total preseure of benzene and 
bromobenzene mixtures at that temperature. Then a streight line is dram from the vapor preasure of bromobenzene to the origin at $100 \mathrm{Mol}$ percent benzene. This line represents the partial vapor presaure of bromobenzene at that temperature. From this partial pressure composition diagram another partial pressure diagram is plotted as shown in Fig. 3. In this diagram the temperature is plotted along the horizontal axis and the pressure along the rertical axis. From Pig. I at aiven composition all the pressures at each constant temperature line are recorded. $A 11$ of these points are plotted on the new pressure temperature diagrem and a curve drawn through them. This Iine represents the constant composition line in the new dlagram. This procedure is repeated for various compositions. Besides this original information, the total pressure minus the rapor preasure of water is plotted on the same diagram. By doing this it is possible to find the total partial pressure of the two liquids being steam distilled. Thus at a giren temperature the intersection of the total pressure minus the vapor pressure of water line with the temperature will locate the composition and the total pressure of the Iiquid mixture being distilled. By using the same temperature and composition it is 
possible to find the partial pressure of each component of the If quid mixture by using the partial pressure composition diagram with constent temperature lines as shown in Fig. I. This procedure is repeated for various temperatures as shom in Table IV.

In Table IV the composition of the rapor is calculated by dividing the partial rapor pressure by the total pressure minus the pressure of the water. Then a plot of $Y$ (composition of the water Iree rapor) rs. $X$ (composition of the water immiscible Ilquid) ismade as show in Fig. 5.

The Rayleigh Equation for batch steam distillation is as follows:

$$
\text { In } \frac{I_{1}}{I_{2}}=\int_{x_{2}}^{x_{1}} \frac{d x}{y-x}
$$

where $I_{1}=$ mols of original charge

$I_{2}=$ mols of residusl ifquor

$x_{1}=$ mol fraction of the more rolatile component in the original charge

$x_{2}=$ mol fraction of the more volatile component in the residual liquor

This sme equation may be used with the developed $Y$ va. $X$ curve in the same manner as for any batch distillation procedure. The ralue of the integral may be 
found by plotting $\frac{1}{y-x}$ re. $x$ as shown in Fig. 7. The area under this curve represents the value of the integral in the Rayleigh Equation. With this curre it will be posible to solve the Rayleigh Equation for any given set of conditions.

By assuming given starting compostion and the final composition of the distillate, one can calculate the total rolume of the distillate. Then keeping the same starting composition and ssuming different final compositions, one can calculate the total volume of the distillate at each assumed final composition. With this infarmation it will be possible to plot a curve of composition of distillate rs. percent rolume distilled orer as shown in Fig 9. Similar curves can be made by assuming different starting compositions. Thus it would be possible to find any of the usual unknown quantities for a distillation of this type with ease. 


\section{TABIE I}

VAPOR PRESSUTE OF BEWZLNE, BROMO BRHZEMIE, TOLUHNE AND WATER AT VARIOUS THMPERATURES (10)

\begin{tabular}{|c|c|c|c|c|c|c|c|c|}
\hline \multicolumn{2}{|c|}{ Benzene } & \multicolumn{2}{|c|}{ Bromobénzene } & \multicolumn{2}{|c|}{ Toluene } & \multicolumn{2}{|c|}{ Water } & \multirow[b]{2}{*}{$760-\mathrm{p}_{\mathrm{H}_{2} \mathrm{O}}$} \\
\hline${ }^{\circ} \mathrm{C}$ & $\mathrm{p}_{\mathrm{C}_{6} \mathrm{H}_{6}}$ & ${ }^{\circ} \mathrm{C}$ & $\mathrm{P}_{\mathrm{C}_{6} \mathrm{H}_{5} \mathrm{Br}^{\mathrm{B}}}$ & ${ }^{\circ} \mathrm{C}$ & $p_{\text {C7H8 }}$ & ${ }^{\circ} \mathrm{C}$ & $\mathrm{P}_{\mathrm{H} 2 \mathrm{O}}$ & \\
\hline 20 & 74.66 & 60 & 27.61 & 15.0 & 16.77 & 50 & 92.51 & 667.49 \\
\hline 30 & 118.24 & 70 & 43.55 & 25.8 & 28.75 & 55 & 118.04 & 641.96 \\
\hline 40 & 281.08 & 80 & 66.22 & 30.0 & 36.70 & 60 & $149 \cdot 38$ & 610.62 \\
\hline 50 & 268.97 & 90 & $97 \cdot 72$ & 40.0 & 59.10 & 65 & $287 \cdot 54$ & 572.46 \\
\hline 60 & 388.58 & 100 & 141.10 & 50.0 & 92.60 & 70 & 233.70 & 526.30 \\
\hline 70 & 547.40 & 110 & 198.70 & 60.0 & $139 \cdot 50$ & 75 & $289 \cdot 10$ & 470.90 \\
\hline 80 & 753.62 & 120 & 274.90 & 70.0 & 202.40 & 80 & 355.10 & 404.90 \\
\hline 90 & 1016.10 & 130 & 372.65 & 80.0 & $289 \cdot 70$ & 85 & 433.60 & 326.40 \\
\hline 100 & 1344.30 & 140 & 495.80 & 90.0 & 404.60 & 90 & $525 \cdot 76$ & 234.24 \\
\hline 110 & 1748.20 & 150 & 649.05 & 100.0 & 557.20 & 95 & 633.90 & 126.10 \\
\hline 120 & 2238.10 & 160 & 846.00 & 110.7 & 760.00 & 100 & 760.00 & 0.00 \\
\hline
\end{tabular}


TABIE II

DEISITY OF BENZHAES-TOIUETE MIXTURES (II) AND

CALCUIATED WEIGHT TS. MOI PERGEOTI

\begin{tabular}{|c|c|c|c|c|c|}
\hline \multicolumn{2}{|c|}{ Benzene-Toluene } & \multicolumn{2}{|c|}{ Benzene-Bromobenzene } & \multicolumn{2}{|c|}{ Benzene-Toluene } \\
\hline Wt. $\% \mathrm{C}_{6} \mathrm{H}_{6}$ & $a_{4}^{25^{\circ} \mathrm{C}}$ & $\mathrm{wt} . \% \mathrm{C}_{6} \mathrm{H}_{5} \mathrm{Br}$ & Hol $\% C_{6}{ }^{\mathrm{H}}{ }^{\mathrm{Br}}$ & wt. $\% c_{7} \mathrm{H}_{8}$ & Hol \% $\mathrm{C}_{7} \mathrm{H}_{8}$ \\
\hline 0.000 & 0.86054 & 0.0 & 0.0 & 0.0 & 0.0 \\
\hline 10.990 & 0.86198 & 10.0 & 5.2 & 10.0 & 8.6 \\
\hline 20.200 & 0.86295 & 20.0 & 12.0 & 20.0 & $17 \cdot 5$ \\
\hline 30.588 & 0.86400 & 30.0 & $27 \cdot 5$ & 30.0 & 26.6 \\
\hline 40.876 & 0.86537 & 40.0 & 24.8 & 40.0 & 36.6 \\
\hline 51.920 & 0.86682 & 50.0 & 33.1 & 50.0 & 45.9 \\
\hline 66.576 & 0.86906 & 60.0 & 42.6 & 60.0 & 56.0 \\
\hline 72.560 & 0.86985 & 70.0 & 53.5 & 70.0 & 66.4 \\
\hline 83.250 & 0.87163 & 80.0 & 66.4 & 80.0 & $77 \cdot 2$ \\
\hline 91.556 & 0.87288 & 90.0 & 81.6 & 90.0 & 88.5 \\
\hline 100.000 & 0.87420 & 100.0 & 100.0 & 100.0 & 100.0 \\
\hline
\end{tabular}


TABIE III

EXPERIIIETTL DATA FOR THE INDEX OF REFRACTION AND

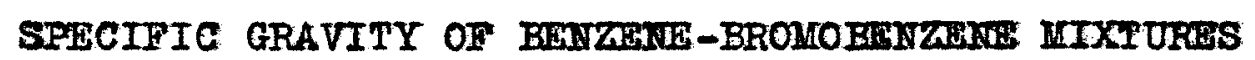

\begin{tabular}{|c|c|c|c|c|c|}
\hline Wt. of $\mathrm{C}_{6} \mathrm{H} 6$ & Wt. of ${ }_{6}^{\mathrm{B}}{ }^{\mathrm{Br}}$ & vt. $\% a_{6} H_{5} B r$ & Lol $\% \mathrm{C}_{6^{\mathrm{H}}} 5^{\mathrm{Br}}$ & Sp. Gr. & Index of Ref. \\
\hline 43.3948 & 0.0000 & 0.00 & 0.0 & 0.8746 & 1.4977 \\
\hline 40.6695 & 4.6748 & 10.30 & $5 \cdot 3$ & 0.9139 & 1.5017 \\
\hline 37.9287 & $9 \cdot 3762$ & 19.82 & 20.9 & 0.9534 & 1.5055 \\
\hline 34.8438 & 14.7243 & 29.71 & $27: 3$ & 0.9990 & 1.5098 \\
\hline 31.4091 & 20.5845 & $39 \cdot 52$ & 24.5 & 1.0479 & 1.5143 \\
\hline 27.6732 & 26.9830 & $49 \cdot 37$ & 32.6 & 1.1016 & 1.5194 \\
\hline 23.4584 & 34.1310 & 59.27 & 42.0 & 1.1607 & 1.5252 \\
\hline 18.1865 & 43.1663 & $70 \cdot 36$ & $54 \cdot 2$ & 2.2366 & 1.5326 \\
\hline 12.7100 & 52.5538 & 80.70 & $67 \cdot 7$ & 1.3120 & 1.5400 \\
\hline 6.9367 & 62.4179 & 90.00 & $81 \cdot 5$ & 1.3950 & 1.5480 \\
\hline 0.0000 & $74 \cdot 3213$ & 100.00 & 100.0 & 1.4950 & 1.5573 \\
\hline
\end{tabular}


TABIE IV

DERIVED DATA FROK COMSTRUCTED THUPHRATURE PRESSURE

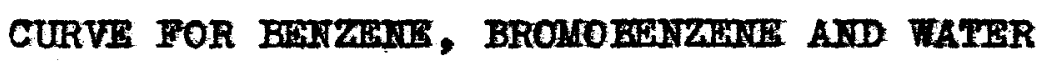

\begin{tabular}{|c|c|c|c|c|}
\hline $\mathbf{x}$ & ${ }^{\circ} \mathrm{C}$ & $\mathrm{p}_{\mathrm{C}_{6}{ }^{\mathrm{H}} 6} \& \mathrm{p}_{\mathrm{C}_{6} \mathrm{H}_{5} \mathrm{Br}}$ & $P_{0}$ of & $\mathrm{C}_{6} \mathrm{H}_{5}^{\mathrm{Br}}$ \\
\hline 100.0 & 69.0 & 535.0 & 0.0 & \\
\hline 90.0 & 71.0 & 516.0 & 5.0 & \\
\hline 80.0 & $73: 0$ & 495.0 & 8.0 & \\
\hline 70.0 & $75: 0$ & 496.0 & 16.0 & \\
\hline 60.0 & $77 \cdot 5$ & 441.0 & 25.0 & \\
\hline 50.0 & 80.0 & 406.0 & 34.0 & \\
\hline 40.0 & 82.5 & $369: 0$ & 44.0 & \\
\hline 30.0 & 85.0 & 322.0 & 55.0 & \\
\hline 25.0 & 87.0 & 295.0 & 65.0 & \\
\hline 20.0 & 88.0 & 267.0 & 73.0 & \\
\hline $15: 0$ & 90.0 & 235.0 & 84.0 & \\
\hline 10.0 & 92.0 & 200.0 & 95.1 & \\
\hline 5.0 & 93.5 & 160.0 & 105.0 & \\
\hline 2.0 & 94.5 & 140.0 & 110.0 & \\
\hline 0.0 & 95.0 & 120.0 & 120.0 & \\
\hline
\end{tabular}


TABIE IV (CONTINULE)

DERIVED DATA FROY COISTRUCTED THMPERATURE PRESSURE

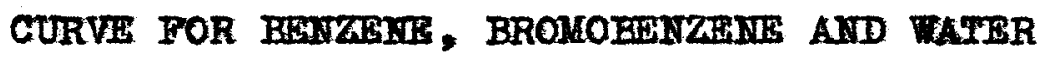

\begin{tabular}{c|c|c|c}
$P_{0}$ of $C_{6}{ }^{\mathrm{H}} 6$ & $Y$ & $Y-X$ & $\frac{1}{Y-X}$ \\
\hline 535.0 & 100.0 & 0.000 & $\infty$ \\
511.0 & 90.0 & 0.090 & 11.10 \\
487.0 & 98.5 & 0.185 & 5.55 \\
453.0 & 96.5 & 0.265 & 3.77 \\
416.0 & 94.5 & 0.345 & 2.90 \\
374.0 & 91.7 & 0.417 & 2.39 \\
325.0 & 88.1 & 0.481 & 2.08 \\
267.0 & 83.0 & 0.530 & 1.89 \\
230.0 & 78.0 & 0.530 & 1.89 \\
194.0 & 73.0 & 0.530 & 1.89 \\
151.0 & 64.5 & 0.495 & 2.02 \\
105.0 & 52.5 & 0.425 & 2.35 \\
55.0 & 35.0 & 0.300 & 3.33 \\
30.0 & 21.0 & 0.190 & 5.26 \\
0.0 & 0.0 & 0.000 & $\infty$
\end{tabular}




\section{TABTE V}

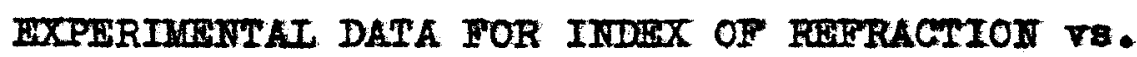

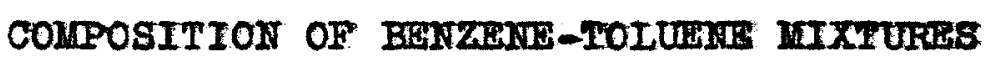

\begin{tabular}{|c|c|c|c|c|c|c|}
\hline Wt. $c_{6}{ }^{\mathrm{H}} 6$ & Wt. $C_{7} \mathrm{H}_{8}$ & Hols $\mathrm{C}_{6} \mathrm{H}_{6}$ & MoIs $\mathrm{C}_{7} \mathrm{H} 8$ & Mols Total & xol $\% \mathrm{C}_{6} \mathrm{H}_{6}$ & Index Rer. \\
\hline$-\cdots$ & $\cdots$ & $-\cdots$ & $-\cdots$ & $-\cdots$ & 0.0 & 1.4935 \\
\hline 1.3850 & 7.1199 & 0.027720 & 0.07720 & 0.09492 & 18.7 & 1.4938 \\
\hline 3.0498 & 5.4725 & 0.039000 & 0.05946 & 0.09846 & 39.8 & 1.4942 \\
\hline 4.7469 & 3.8077 & 0.060600 & 0.04230 & 0.10190 & 59.6 & 1.4950 \\
\hline 6.6493 & 2.0025 & 0.085000 & 0.02175 & 0.10675 & 79.6 & 1.4962 \\
\hline$\cdots$ & $-\cdots$ & - & $-\infty-\infty$ & $-\infty$ & 100.0 & 1.4979 \\
\hline
\end{tabular}




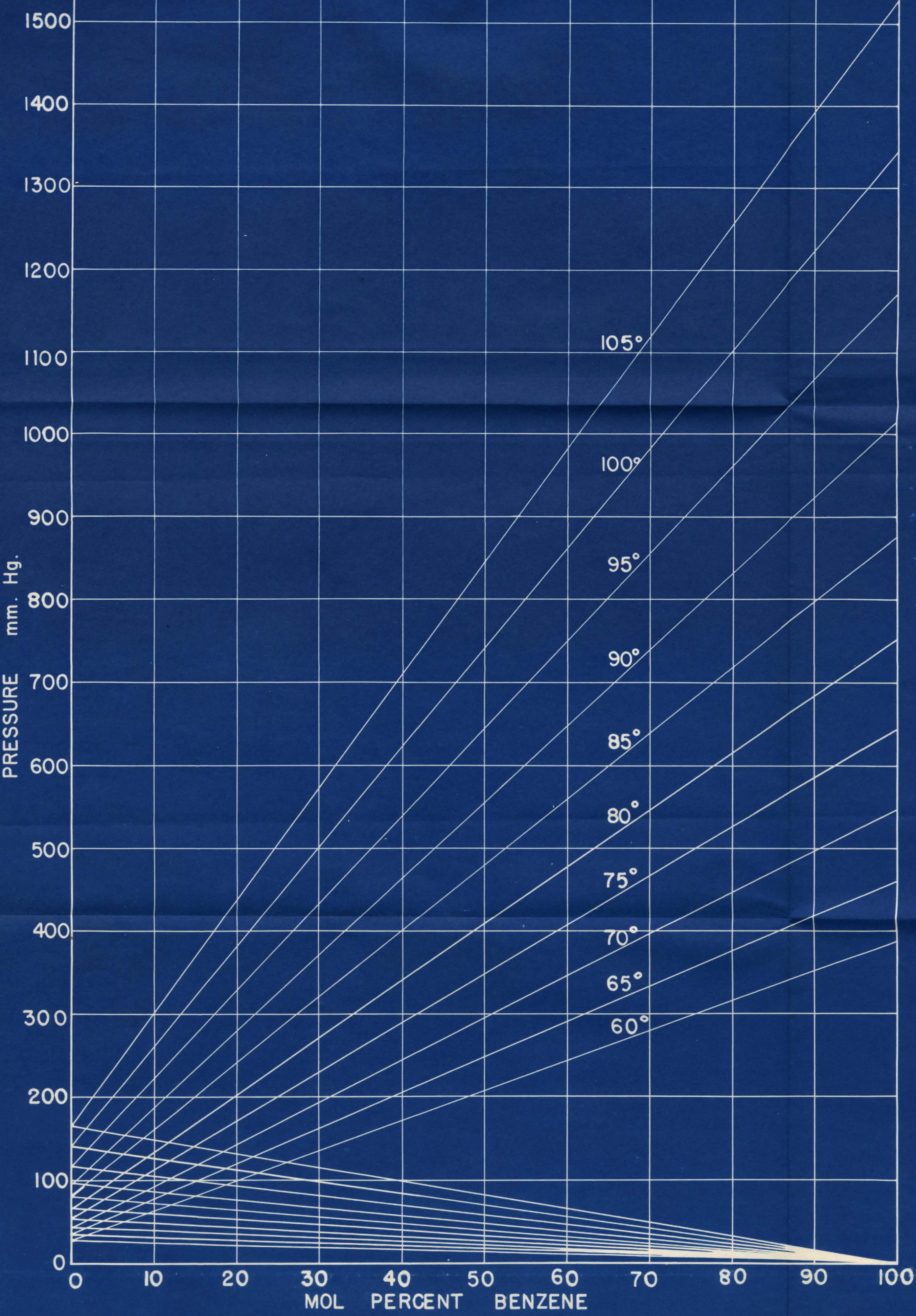




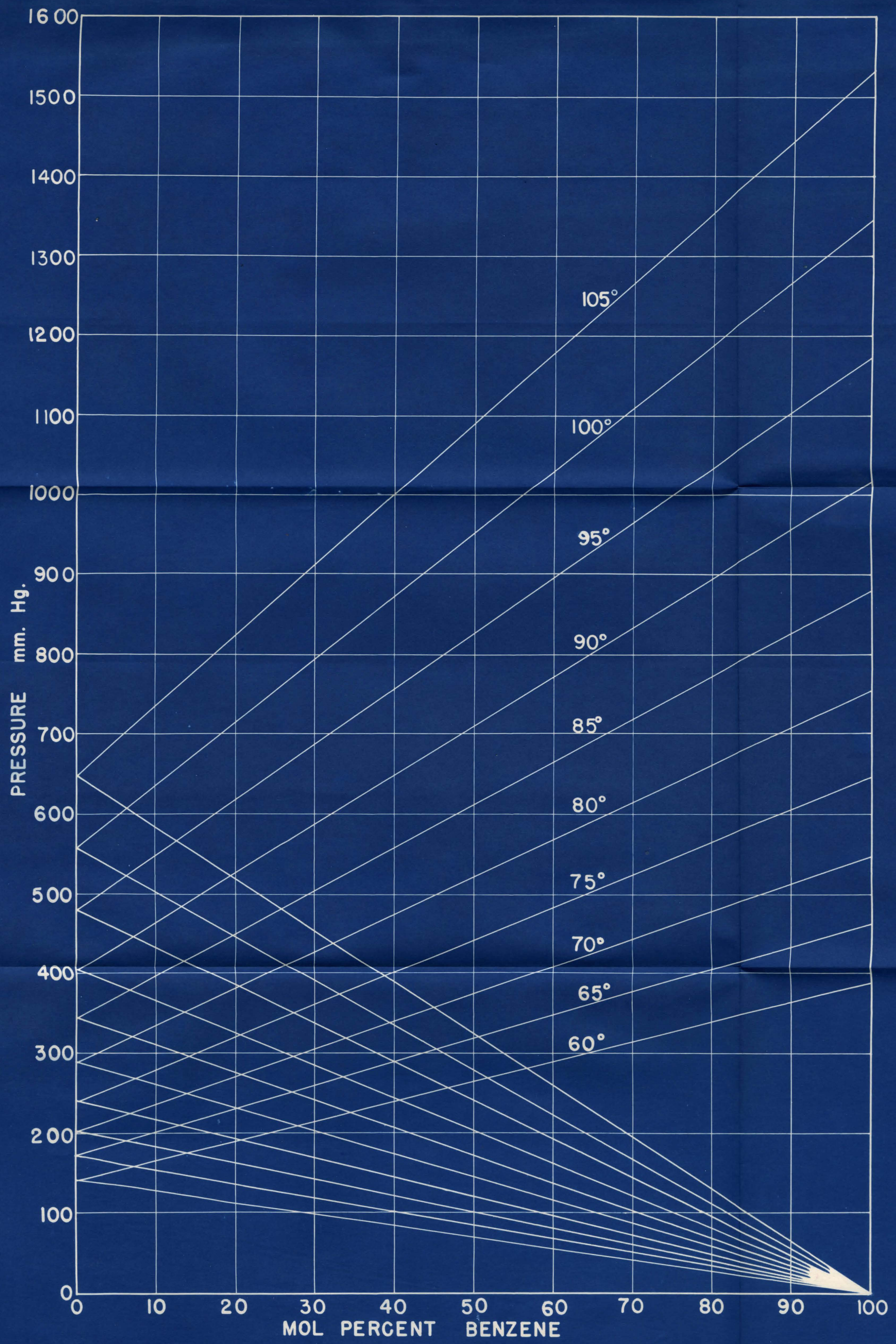




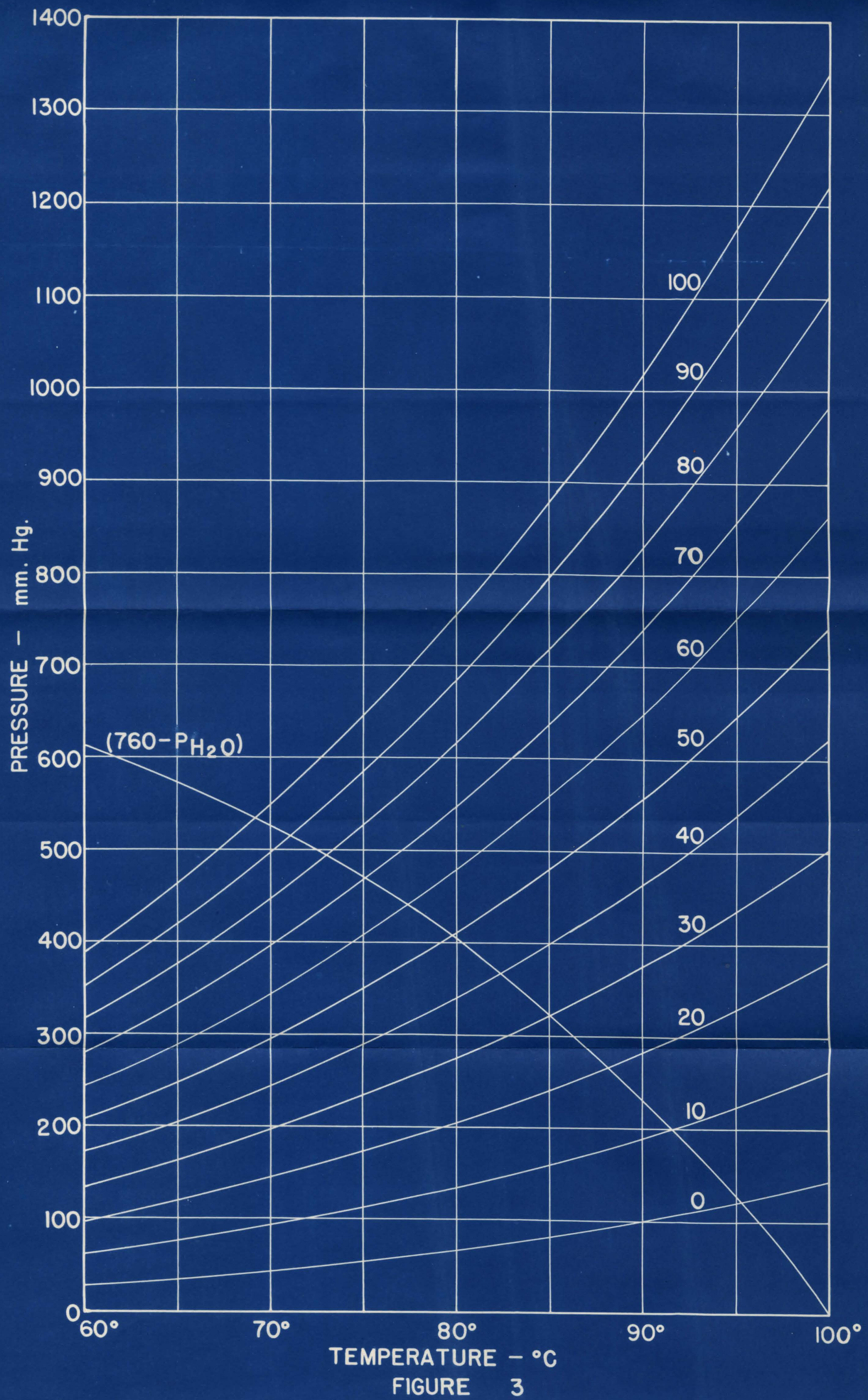

VAPOR PRESSURE OF BENZENE AND BROMOBENZENE VS. TEMPERATURE AT CONSTANT MOL PERCENT LINES 


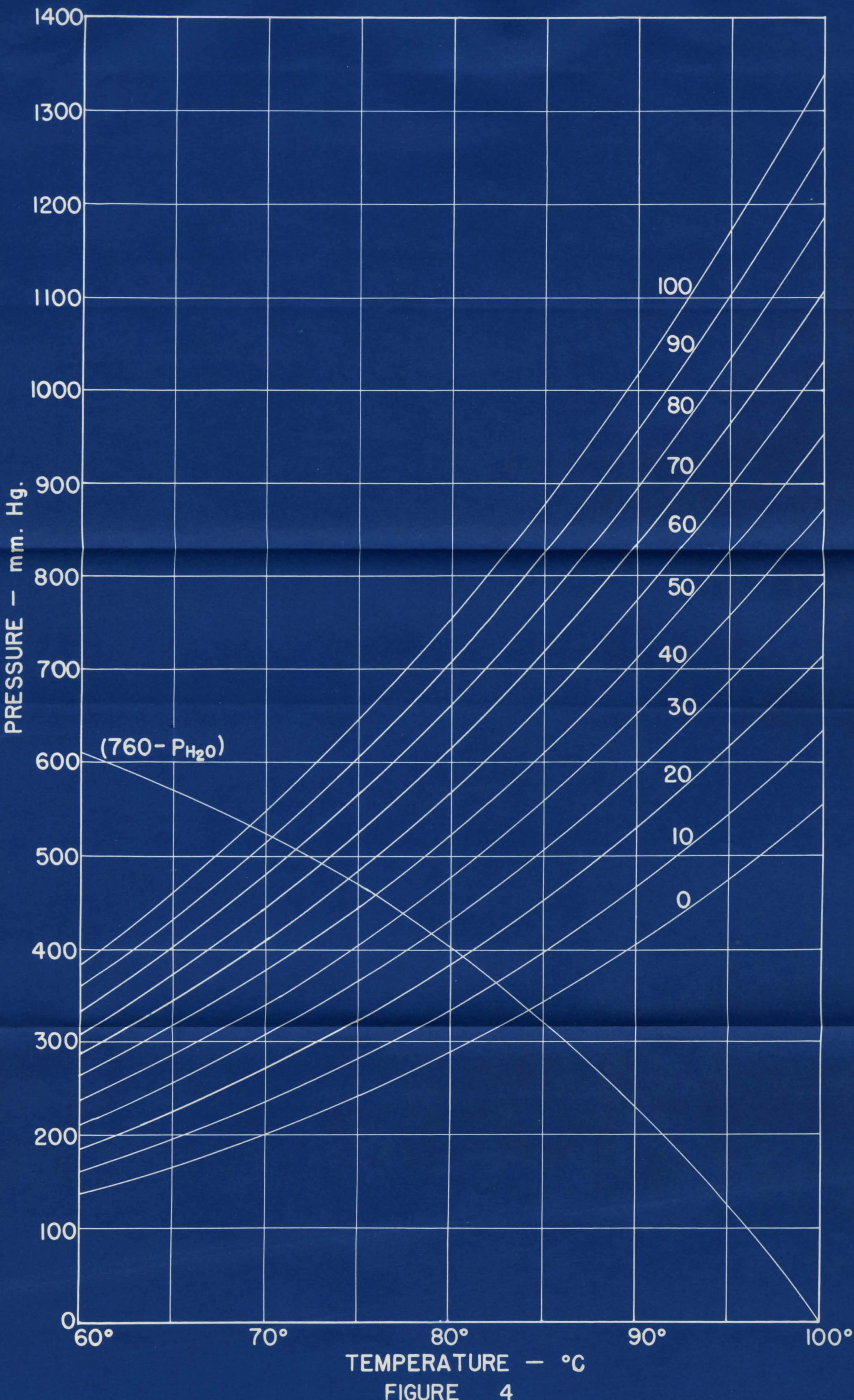

FIGURE 4

VAPOR PRESSURE OF BENZENE AND TOLUENE VS. N TEMPERATURE AT CONSTANT MOL PERCENT LINES 


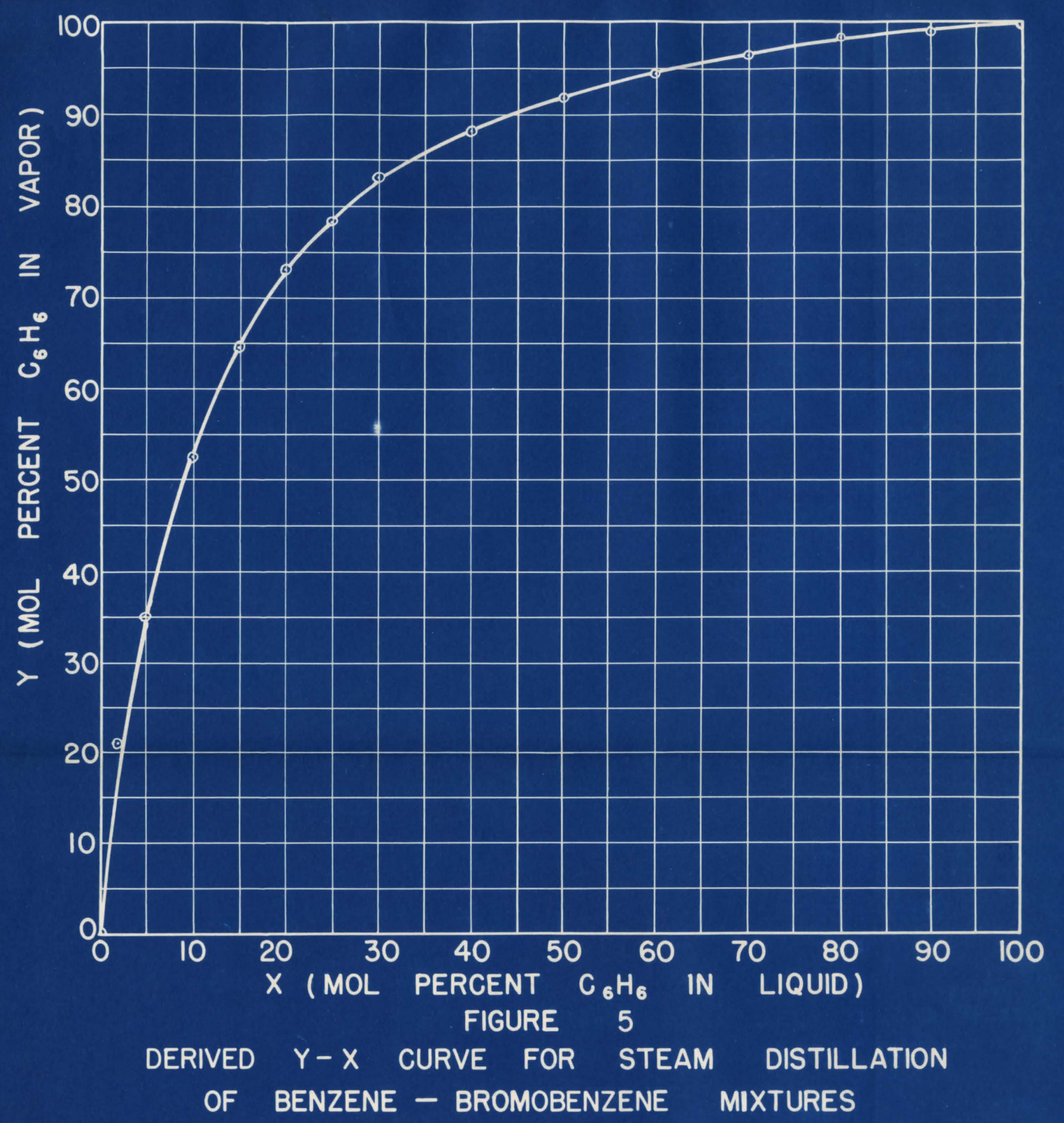




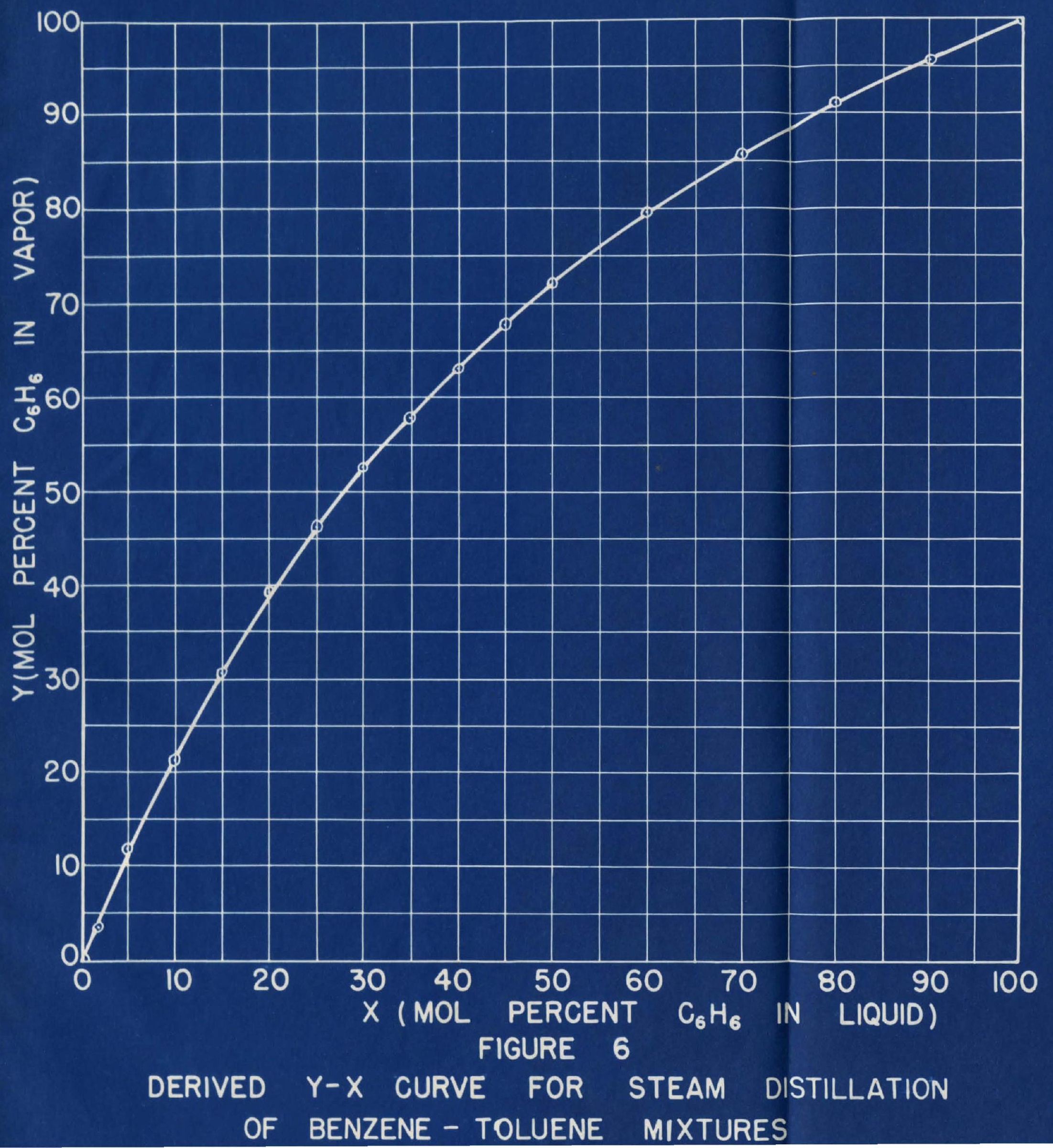




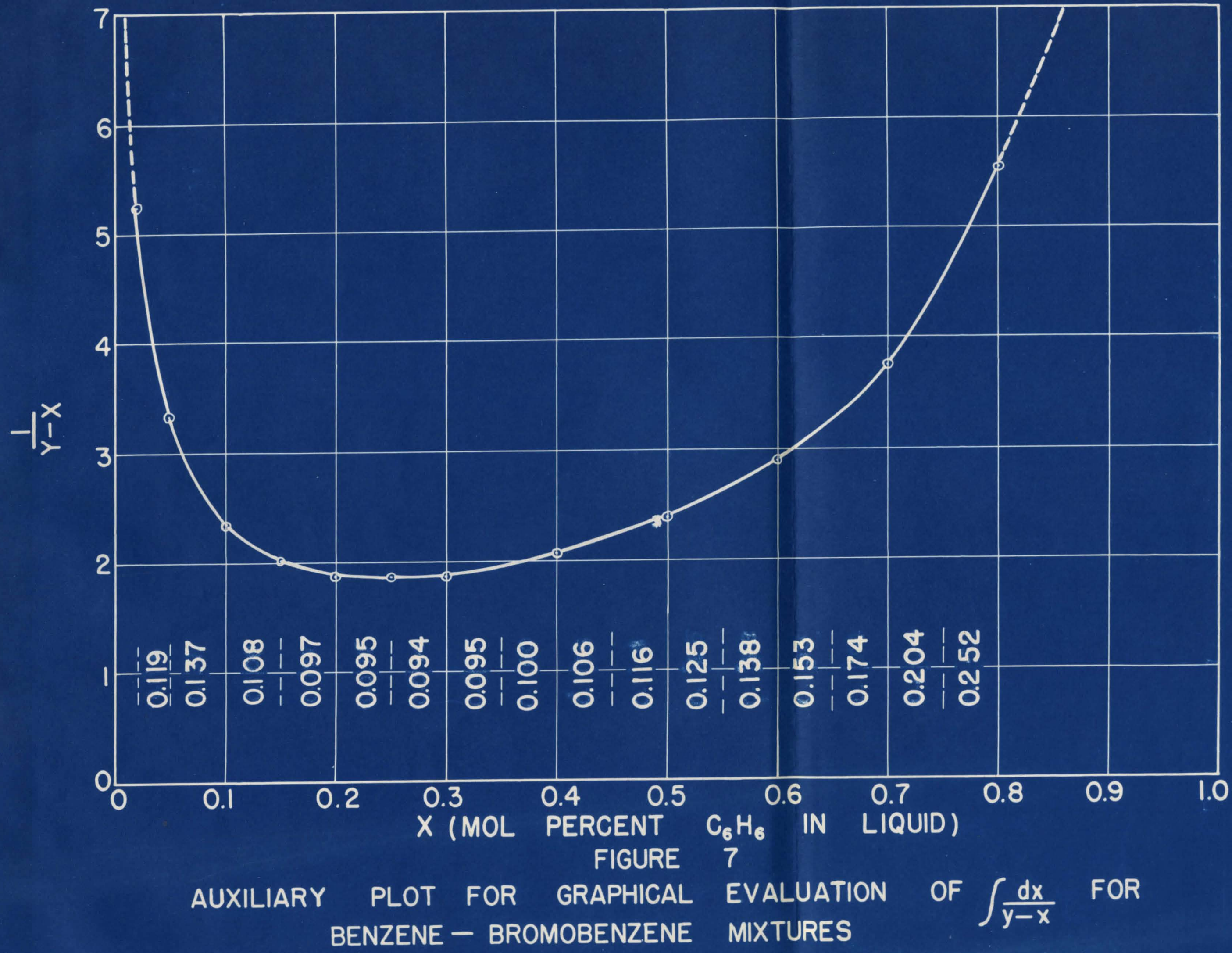




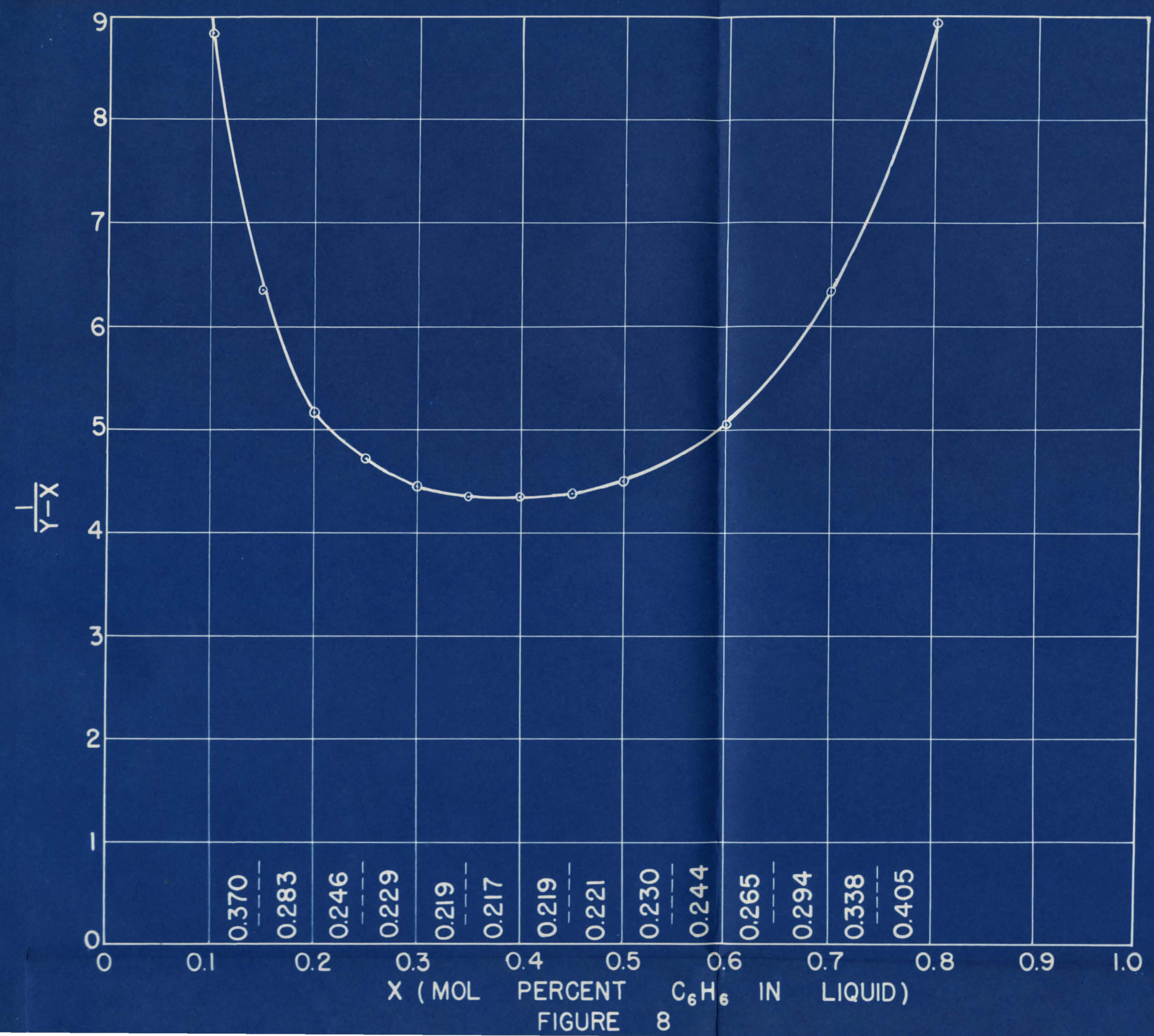


EXPERIEIAI 
The results of the graphical procedure could be checked only by comperison with results from stean distiliation experiments. In order to preform the experiment, an accurate method to determine the compoeftion of the distiliate had to be derised. Since the index of refraction rarfes with the composition of a distiliate, it is sometimes posefble to use the index of refraction for determinations of compositions. An examination of the systems wich falfilled the fnftial requirements of misetbility for the two components, immiactility with wer, and at the same time having wide boiling point range, high differences in refractive index and densities, and all the wile holding close to the characterfitios of Ideal solutions lead to the ohotce of benzene-bromobenzene syatem. Hixtures of these two components were prepered and the indices of refruction measured with an Abbe refractometer. From this data the index of refraction ve. the composition of the liquide curve was plotted as ahown in Fig. 11. From the known composftions of this series of IIquide the opecific gravity likewise nas meatured and a ourve of specifie gravity vo. Index of refraction was plotted as show in Fig. 13. Wlao - curre of composition of the Ilquids ve. the specifie grafity was plotted as strom in Pig. 15. 
After this preliminary experimental work the actual steam distillation experiment was set up. A three-neck liter flask was used as the still pot. This three-neck flask wa placed in a container, well insulated win asbestos. A thermometer was placed in one neck and a glass stem nozzie that rent to the bottom of the Hask was placed in another neck. This glass steam nozzle distributed the stean eveniy throughout the bottom of the flask. The stean was generated by using a lifeker burner under a liter flakk half full of nater. The third and midle neek of the Plask is comnected through a three way atop cock to a rertical water condenser. From the other side of this three way top cock a large glass goose neck was comnected to a water condenser inclined so that the condensate would run through an adapter into $15 \mathrm{ml}$. centrifuge tubes. The goose neck of the three way atop cock was mapped with about four feet of resistance wire which was comected to an electrical ctroutt. This resistance wire heated the goose neck and kept the rapors from condensing: A sketch of the apparatus may be seen in Pig. 17. mumerous trial rums were made before this experimental set-up was finaliy assembled.

The experiment wa preformed in the following manner. $\Delta$ colution of the two liquids was made up 
and its" Index of refraction determined. The rolune of the solution was mexsured and then the solutfon was poured into the three-neak if ter rlask. A Meker burner was Iighted and placed under the liter flask wich was half full of water. The two way stop cock was placed in such a position that the rapors coming from the three-neck flaskwould rfie up in the vertical condenser. The water was turned on both water condensers and the circuit wich contained the heat resistanoe wire, was closed so that the goose neek would heat up. When the water in the flask started to boil, steam entered the three-neck flask and was evenly dispirsed throughout the Iiquid in the bottom of the flask. The steam gradarily heated up the liquid mixture until rapors started to come up in the vertical water condenser. Thiscondenser was rery effictent and returned essentialiy all the rapors as liquid to the flask. The amount of the vapor being condensed could be controlled by controlling the amount of gas to the Heker burner. The solution was allowed to steam distIII under total refIux for about ten minutes. This gave the equipment sufficient time to heat up so that heat losses would be kept at a minimum during the experiment. Lt the and of ten minutes the rate of distillation wes reduced so that practically no rapors 
were going to the rertical water condenser. Then the two way atop cock was changed so that the vapors from the flask would go up finto the goose neak and then into the inclined condenser. After the stop cock was turned the rate of steam to the flask was increased again so that the distillation rate would be increased. The heat resistance wire around the goose neck kept the rapors in the goose neck from condenging. As the rapors condensed in the fnclined water condenser, the Iiquid ren down through an adapter into a small receiving chamber wich had a top cock in its outIet. The outlet of this chamber was placed in a $15 \mathrm{ml}$. centrifuge tube. When this centrifuge tube has half full of distillate, the temperature of the vapor in the three-neck flask was recorded. As this $15 \mathrm{ml}$. centerfage tube was filled up, the stop cock in the outlet of the small chamber was turned off. Nnother centrifuge tube was placed under the outlet of the small chamber and the stop cock in the outlet of the chamber was opened. Then the previous sample was stoppered and the total rolume of the sample recorded. Ints procedure was repeated until the temperature of the vapor in the flask started to go above $95^{\circ} \mathrm{C}$. Then the Heker burner was turned off and the equipment was allowed to set a few minutes until all of the distillate 
had drained into the centrifuge tube. AII of the samples collected during the experiment contained water plus a mixture of the two liquids. These samples were all centerifuged in order to obtain a good separation of the water from the mixture of the two Iiquids. Then the amount of water in each sample was recorded. The Iiquid mixture layer composition was found by determining the findex of refraction of the Iiquid mixture layer in each sample. The liquid remaining in the three-neak flask was poured into a graduate and the rolume of the Iiquid mixture measured and recorded. The Ifquid mixture composition was found by determining the index of refraction of the mixture. This experimental procedure provided sufficient deta for calculation of the desfred curres.

After the experfmental data was obtained, a curve of the true rapor temperature ra. temperature calculated from the composition of each sample collected, was plotted as shom in Pig. 18. A curve of weight percent of Ifquid composition rs. mol percent of liquid composition was plotted as show in Fig. 20 in order to calculate the curve of composition rs. percent rolume distilled over. Bxperimental data was obtained for three different atarting compositiona using benzene, bromobenzene mixtures. The graphical procedure was 
calculated using the saue starting compositions and the resulta are compared in Fig.9. A similar procedure was followed for benzene-toluene mixtures and the series of curres, Pigs, $2,4,6,8,12,14,16$, 19. and 21 culminate in the final comparison curres In 18.10. 


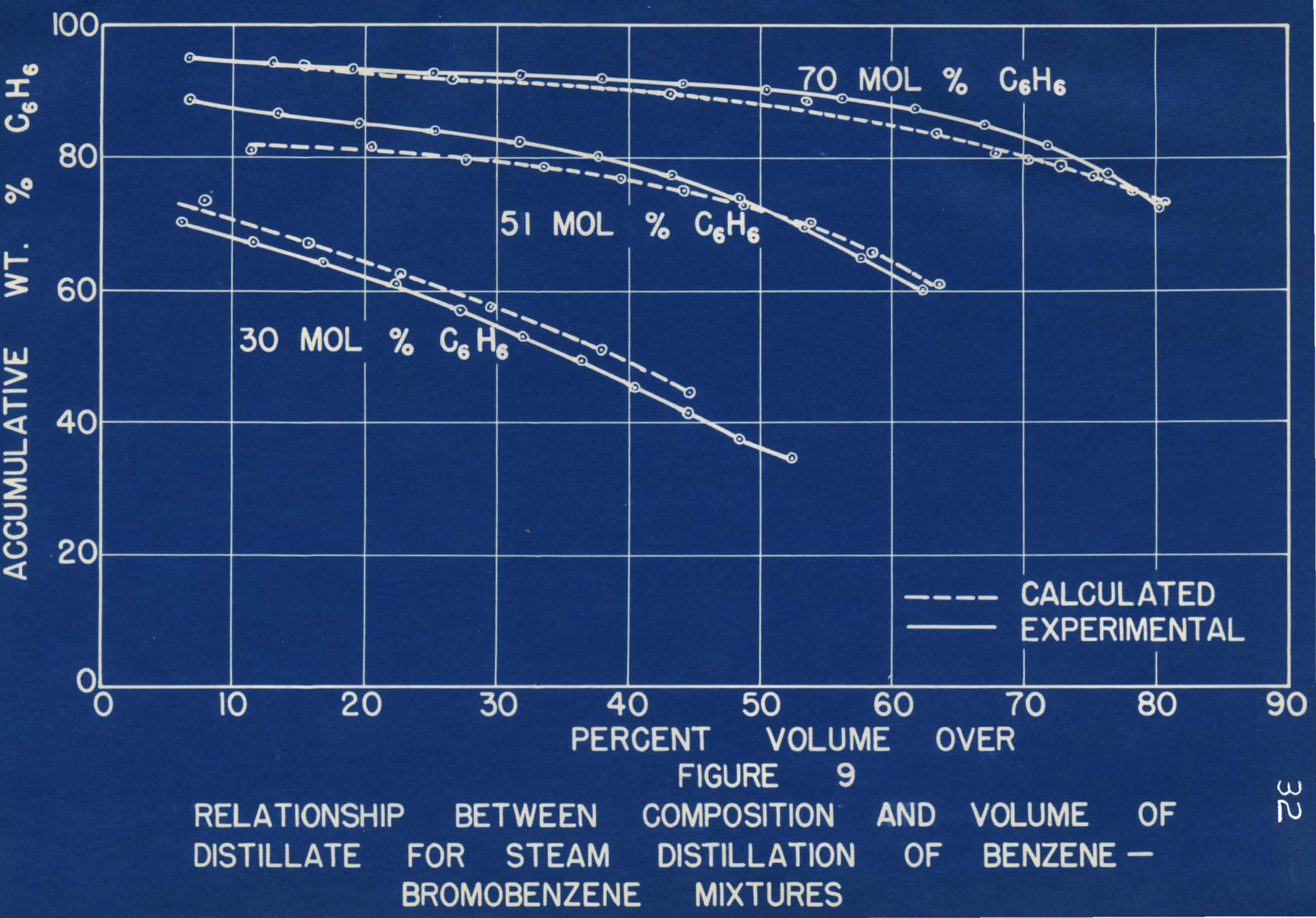




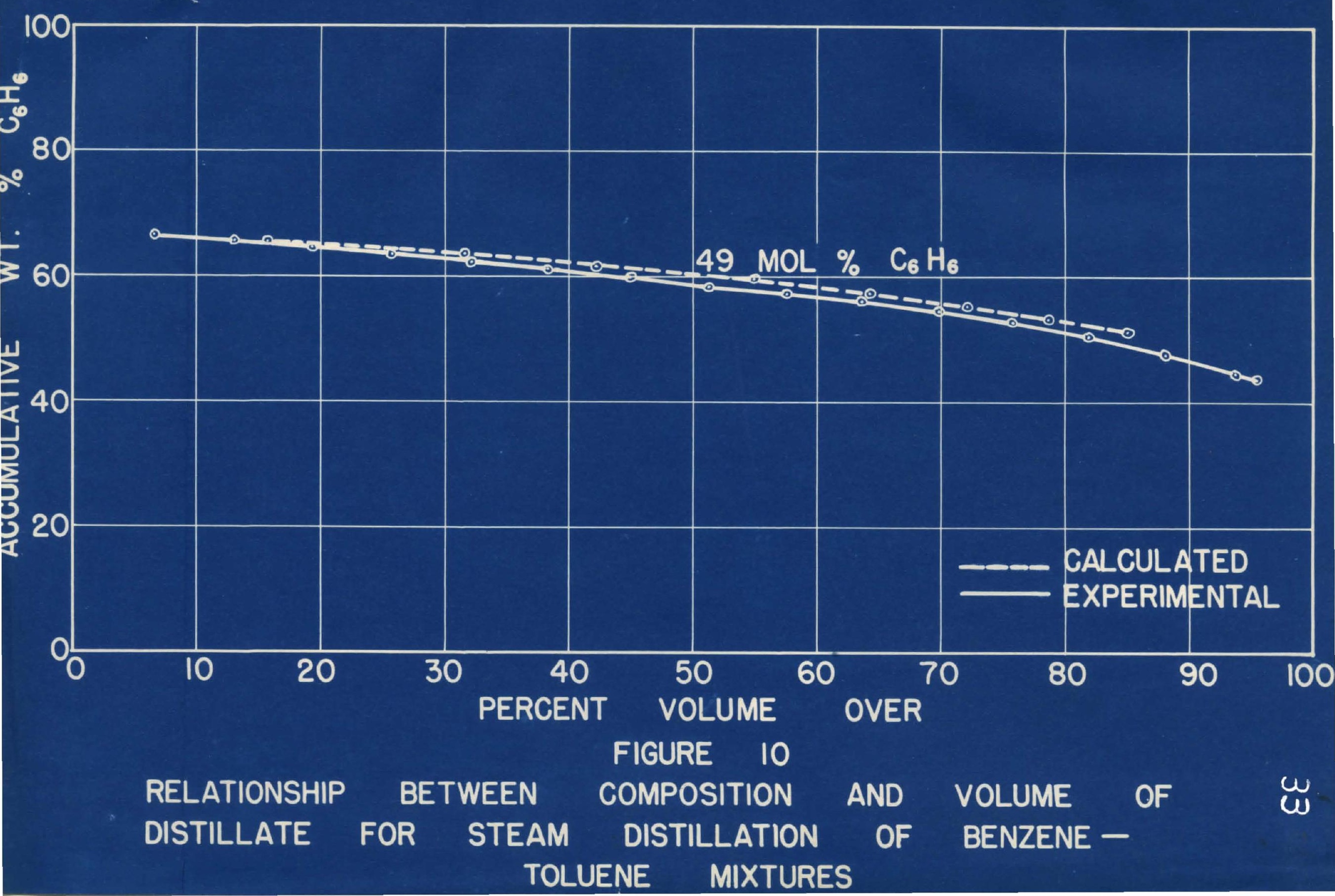




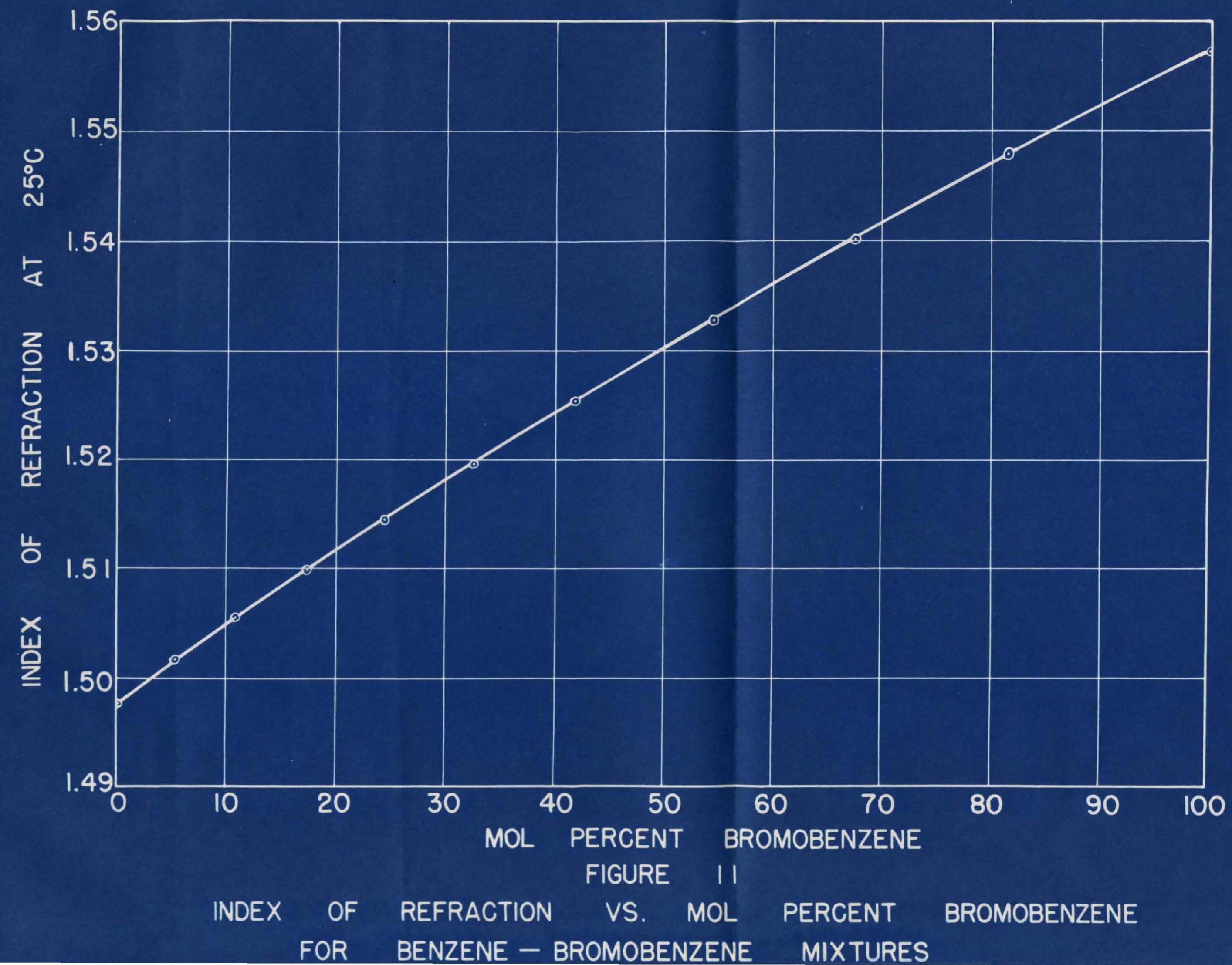




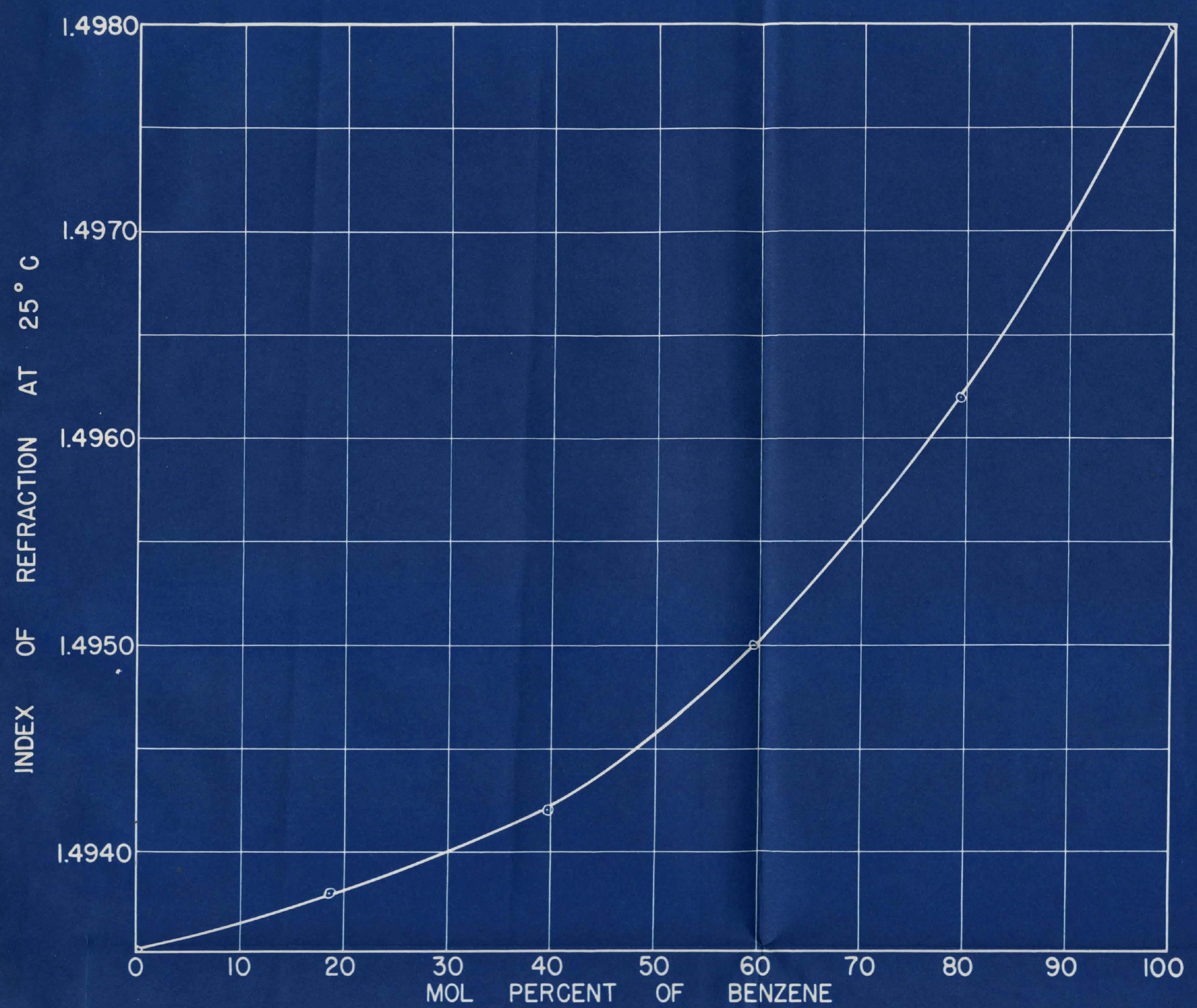




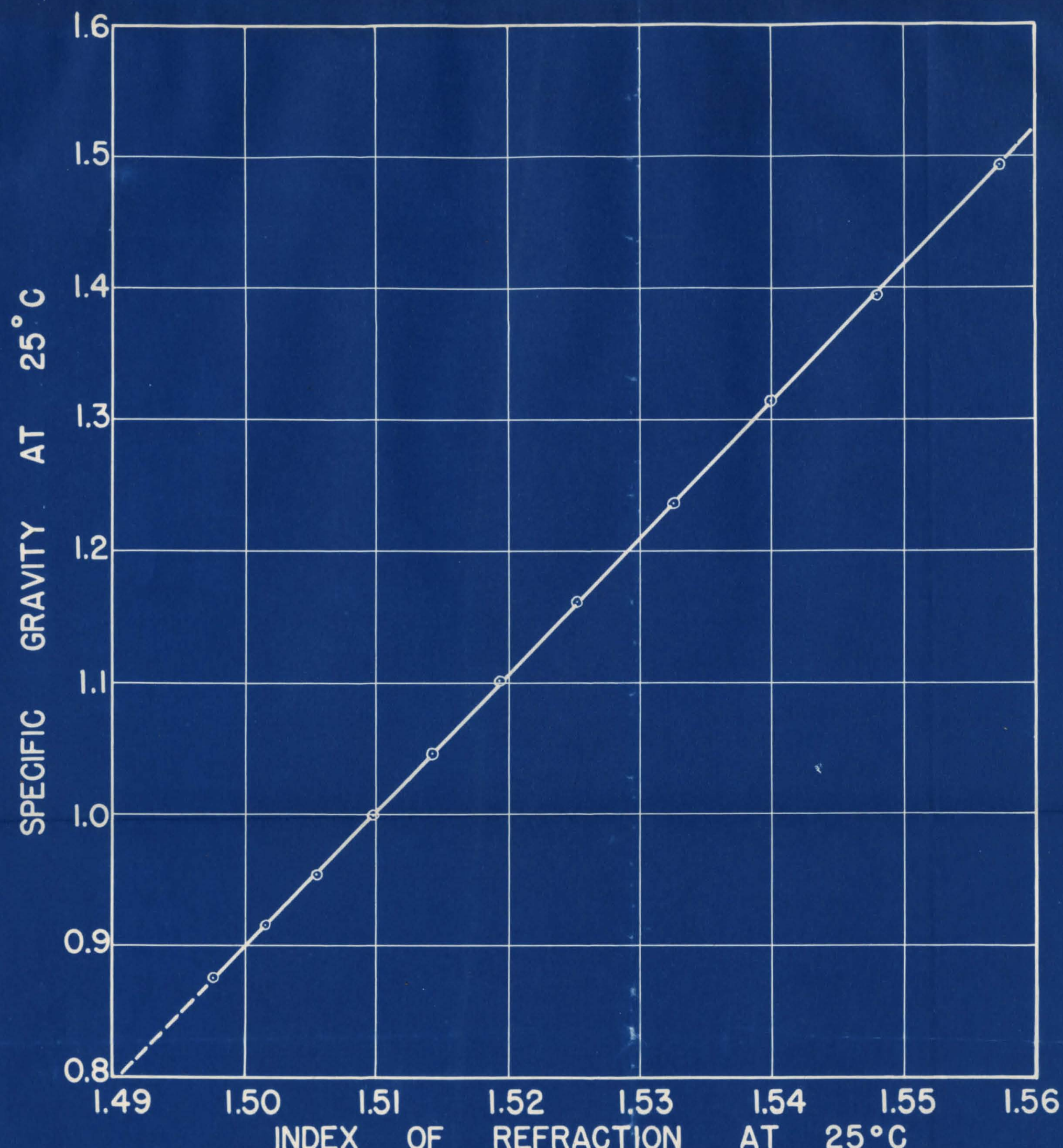

FIGURE 13

SPECIFIC GRAVITY VS. INDEX OF REFRACTION FOR BENZENE - BROMOBENZENE MIXTURES 


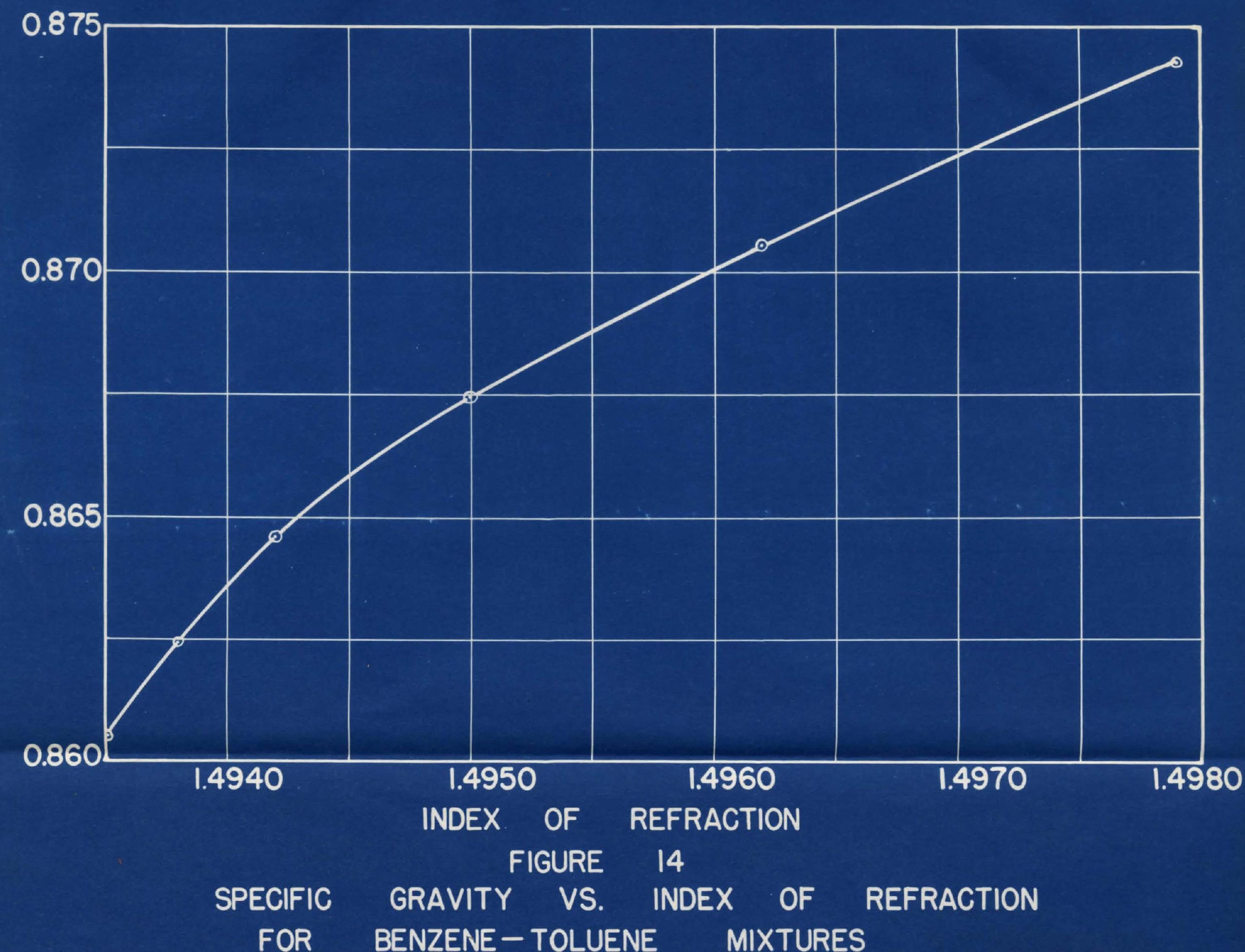




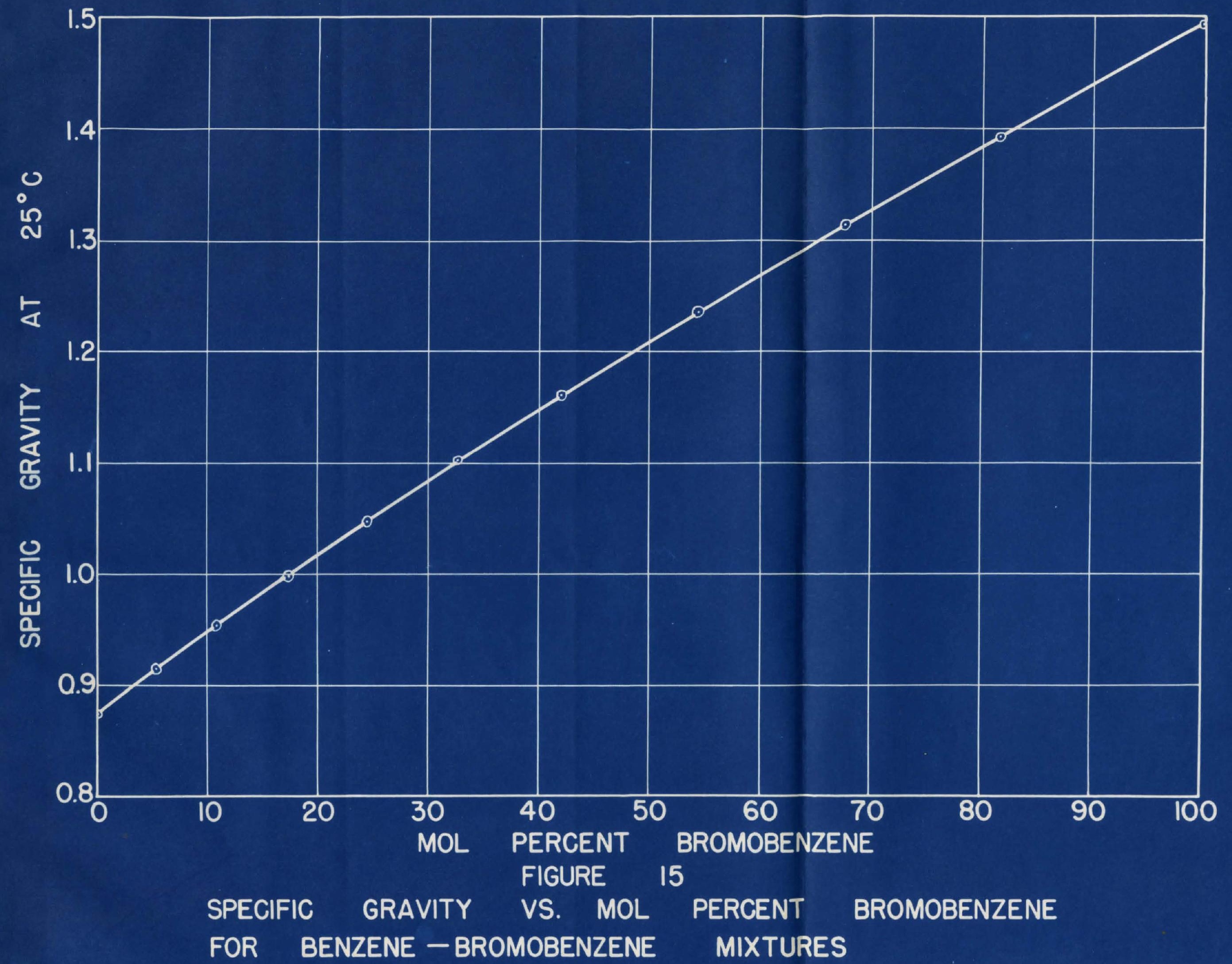




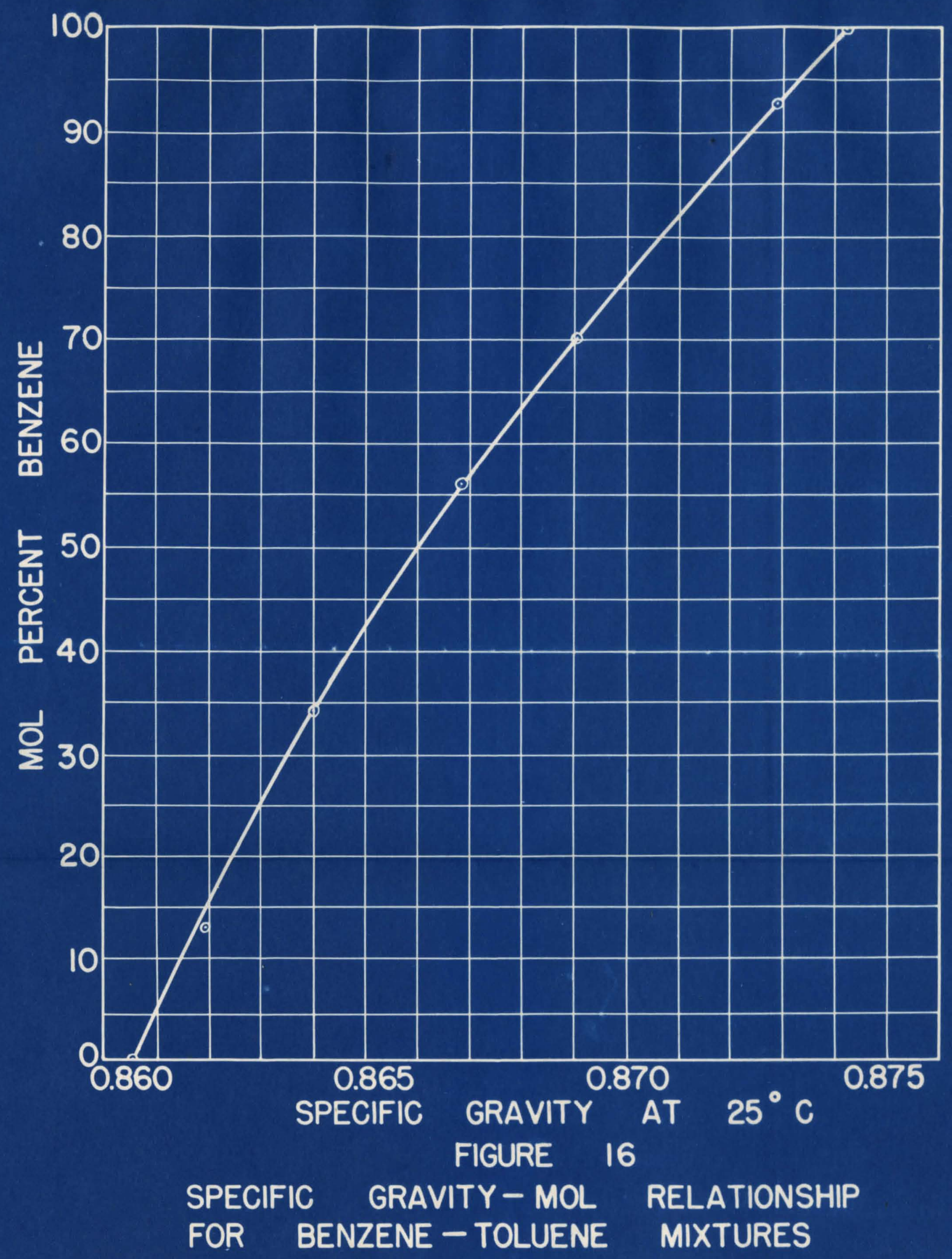




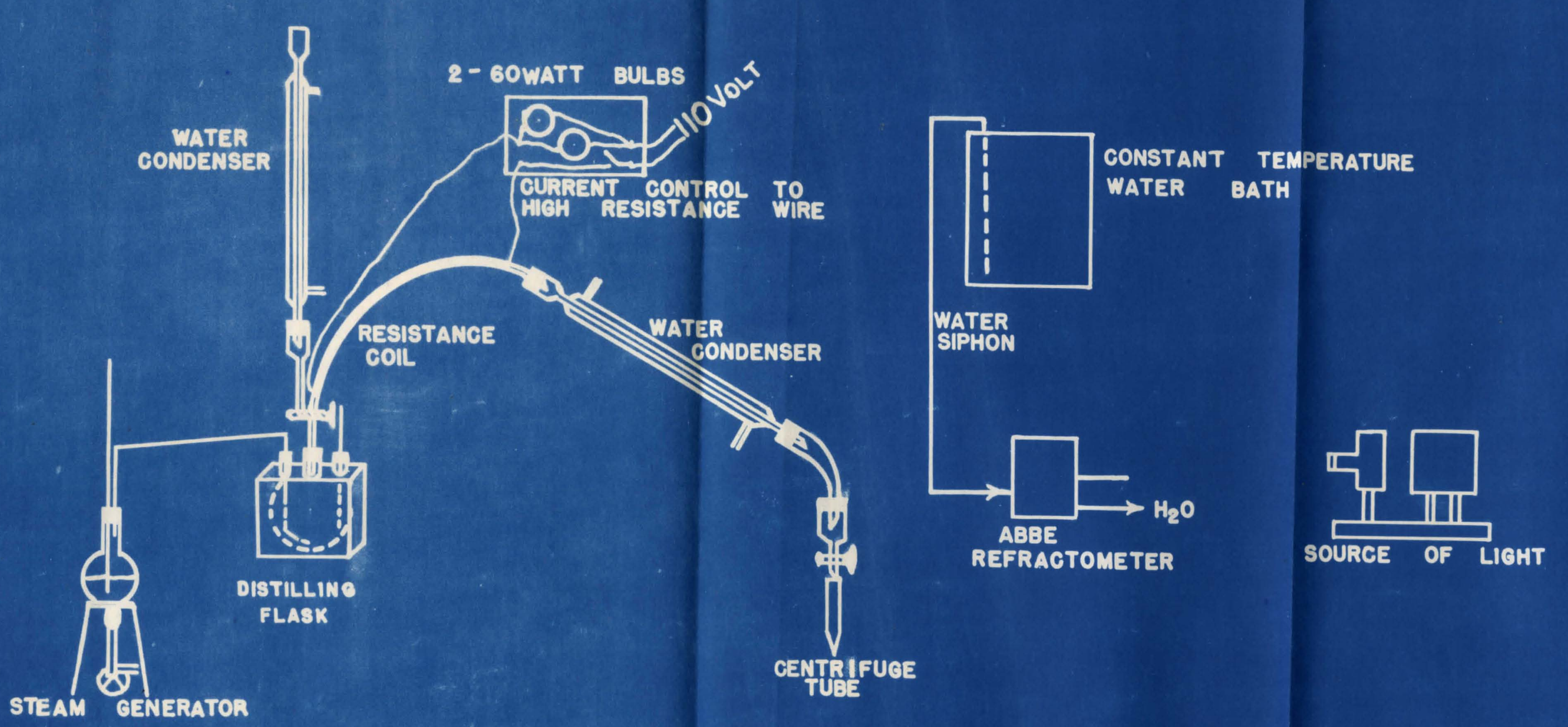




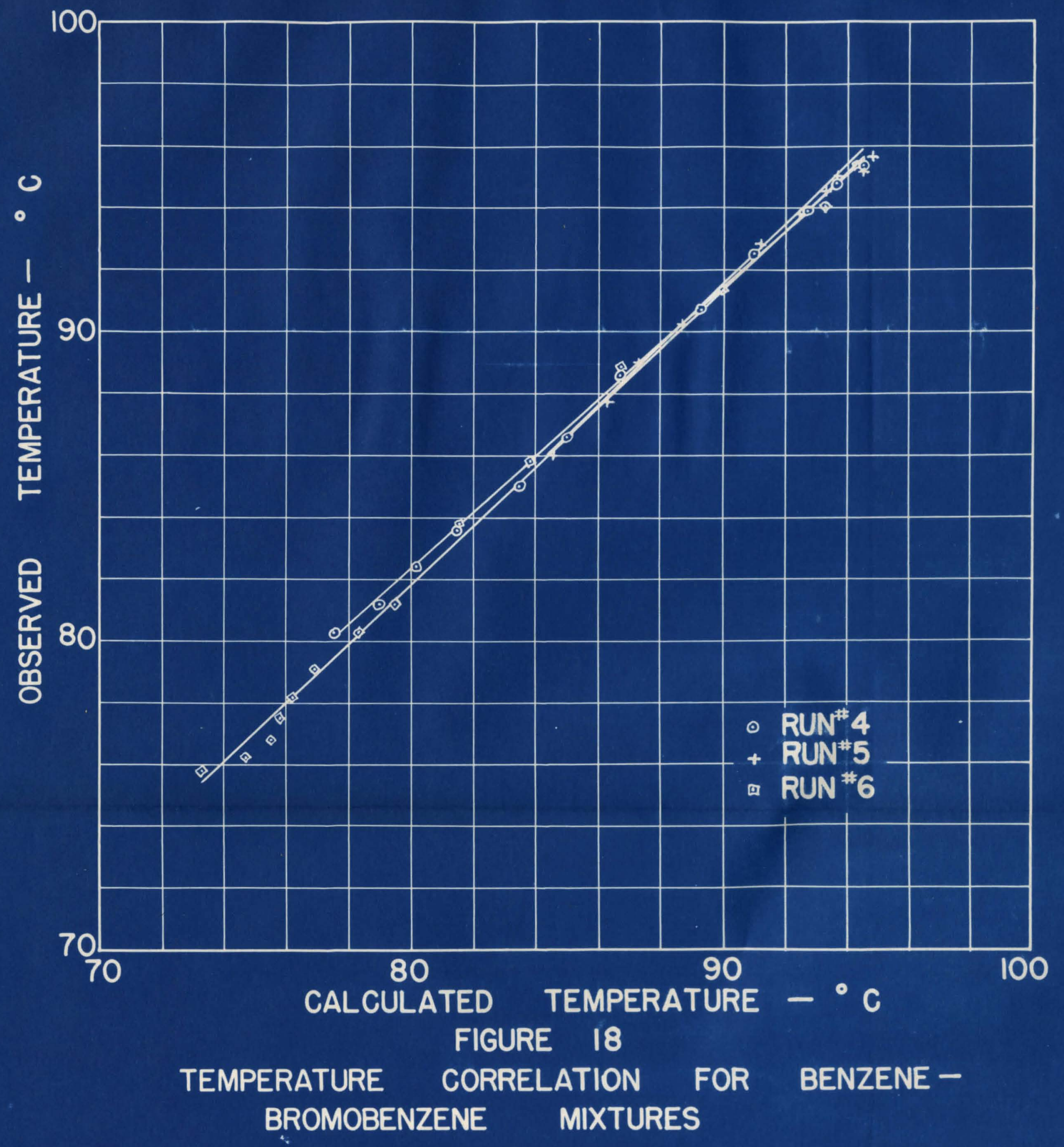




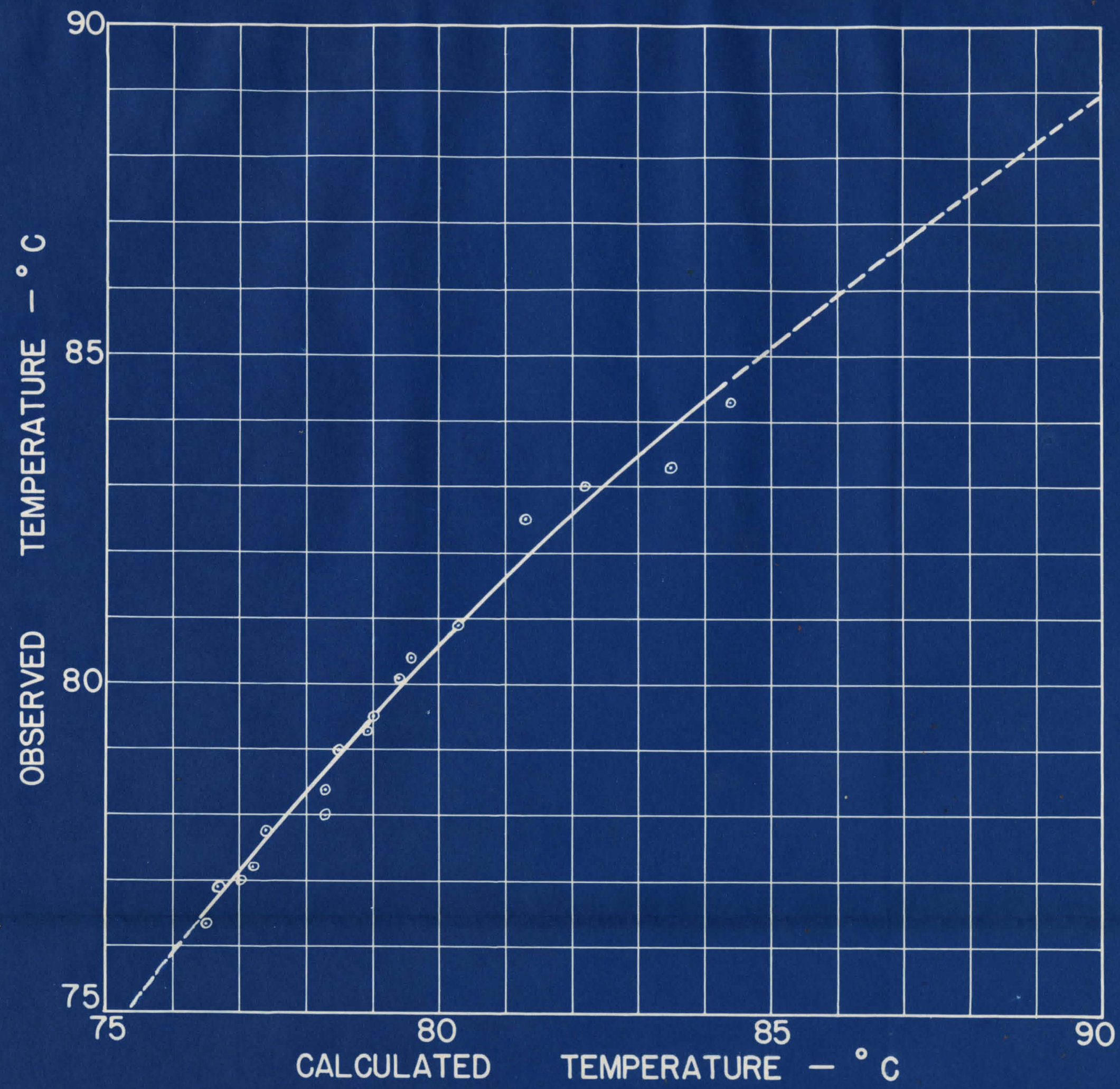

FIGURE 19

TEMPERATURE CORRELATION FOR BENZENE TOLUENE MIXTURES 


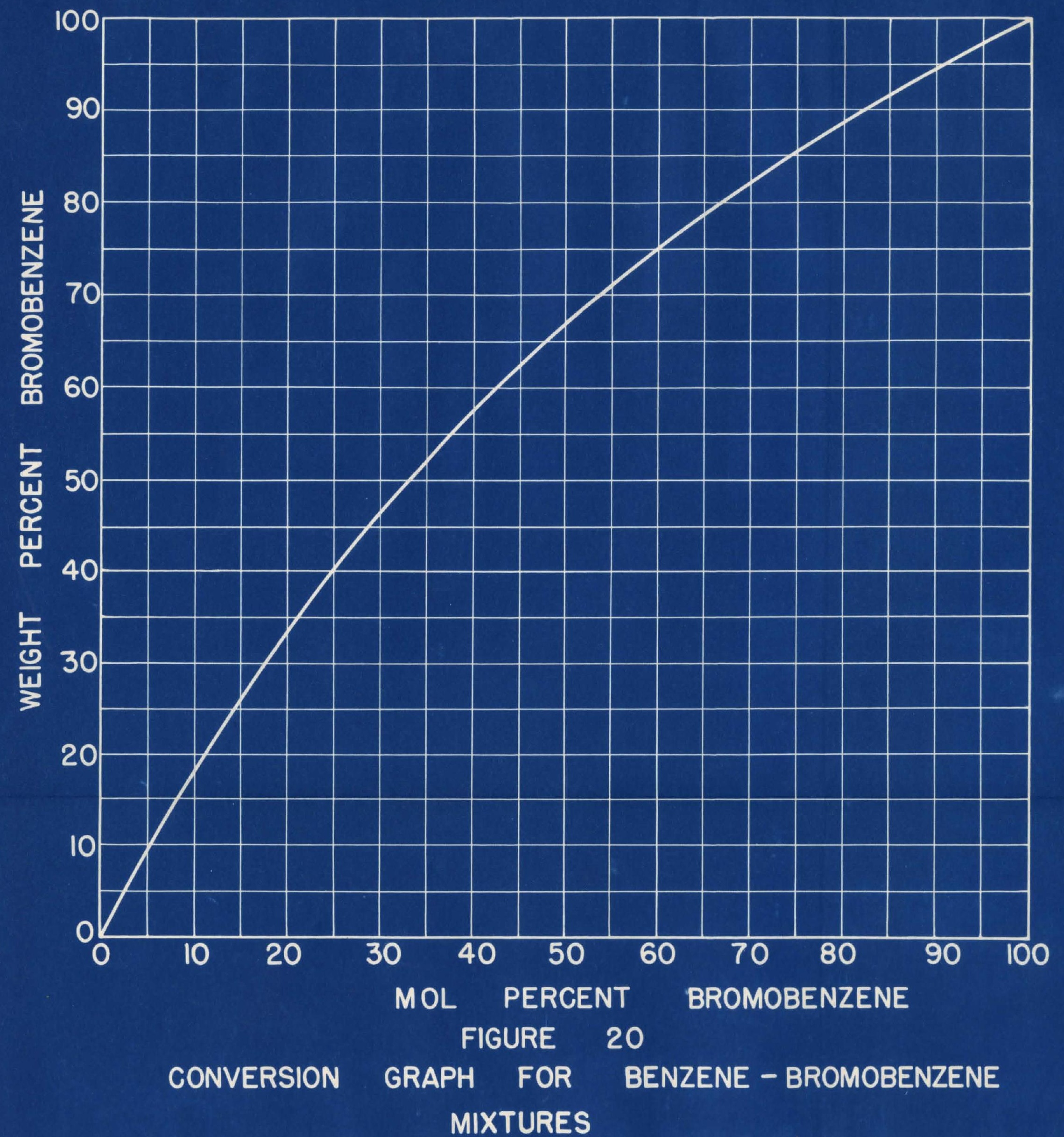




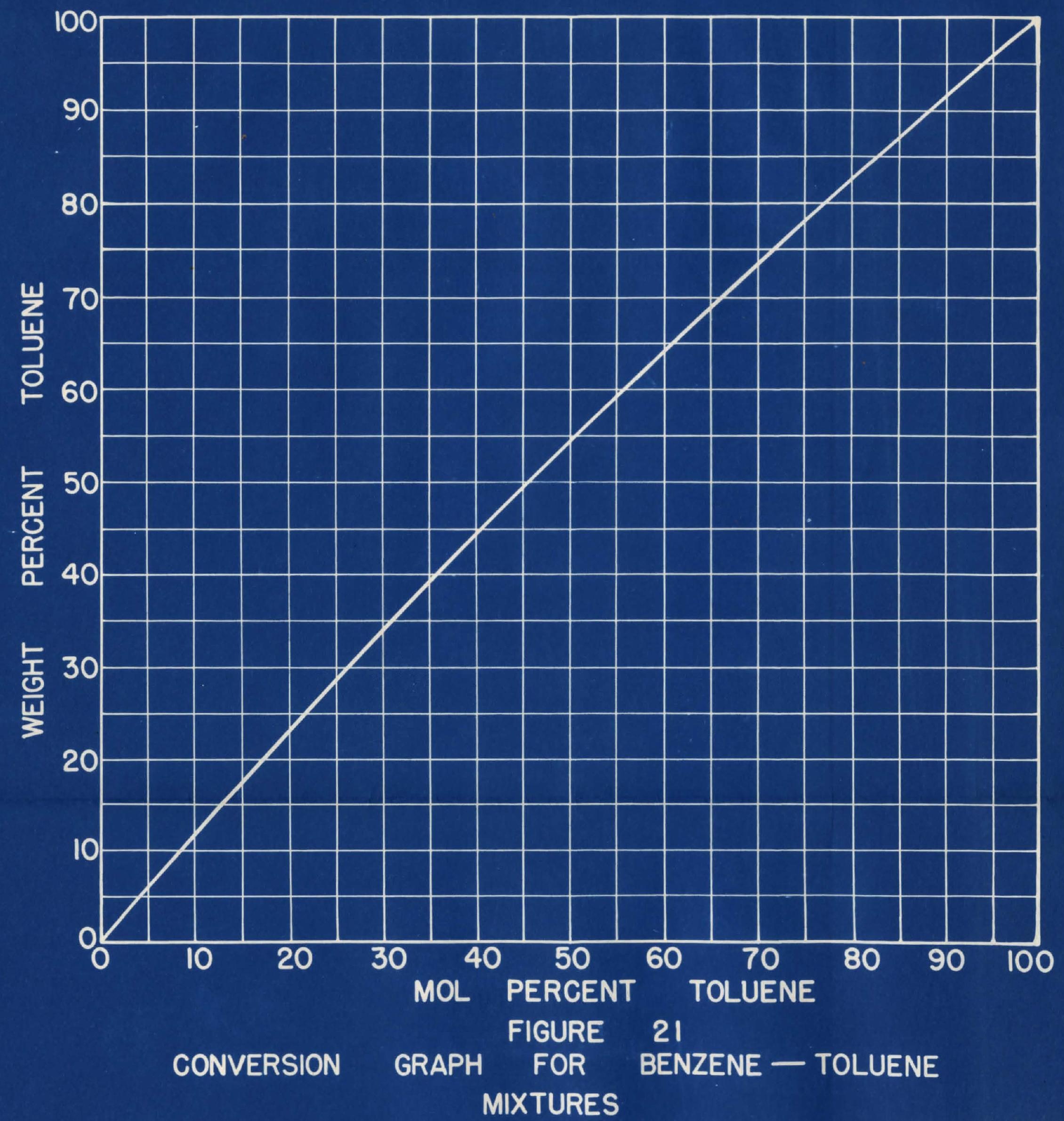


DISCUSSION 
The infitial condftion of each experimental run was used as a starting point for each graphical solution corresponding to that run. The results obtecined by the grephical procedure were then compared with the experimental regults in order to check the graphical procedure for validity. This comparison was made by plotting the results as composition of the distillate v8. percent volume of the original charge distilled over. If these two curres did not coincide there were three possible simple explenations. Pirst, there may be somo experimental error due to faulty procedure or equipment arrangement. Secondly, the tro miscible liquids ased in the distillation may not obey Raoults" Iew. If this is the case there wil be a deriation between the two curves because the graphical procedure is besed on the assumption that the two If quids used do obey Raoults' Law. The third possible explanation is that the graphical procedure itself is not correct.

A comparison of the experimental results using benzene-bromobenzene mixtures with the graphical calculated reaults is shown in Fig. 9. For a starting composition of 70 mol percent the agreement between the two curvea is rery good. At 51 mol percent starting composition both curves have similar shapes al- 
though one curve appears to have a slightly different slope than the other one. The 30 mol percent starting composition curves have exactly the same shape and slope even though there is a small deriation between them. It should be noted that at $70 \mathrm{~mol}$ percent the calculated curve lies belor the experimental curve and exosses it at one end. At 51 mol percent about threo-quarters of the culculated curve 11 es below the experinental curve and the reat is above. While at $30 \mathrm{~mol}$ percent the calculated curve is completely above the expertmental curve. Thus going from a higher mol percent benzene starting composition to a lower mol percent benzene starting composition, the calculated curre ohanges from belor to above the expertmental curve. The point at which both curveg cross, woves from right to left as the mol percent benrene starting composition decreases. At $30 \mathrm{~mol}$ percent the peint has apparently mored beyond the left end of the curve, leaving the calculated curve completely above the experimenteI curve. By comparing the left aide of the curres it is noticed thet at 70 mol percent both ourve practically coincide while at 51 mol percent there is a large deviation between the curves. At $30 \mathrm{~mol}$ percent there is a constant deriation throughout the total length of the 
curves.

A compartion of the experimental reeults uafing benzene-toluene mixtures with the graphical calculated reanlts is show in $\mathbf{1 g}$. 10. With a gtarting composition of 49 mol percent the agreement between the two curves is very good with the calculated curve completely above the experimental curve. This deriation of measured from calculated potnts Is not serious. It represents a real atfrerenes, but the values on an orerull basis are well within. necesaery predictions for mgineering calculatione. During the experimental run when each centrifuge tube was exact $2 y$ half full the temperature of the vapor above the botling Ifquid was recorded as the observed temperature. The campositian of each gomple was used in Fig. 3 or 4 to determine the tew perature at witioh the composition of the rapor above the boiling mixture correepends to the componition of the semple colrected. 4 plot of the oberred temperature va. the al oulated temperature is ahown in Fis. 18 and 19 . It is very signifiemat that aI three temperature curves for mixtures of benzene and bronobearene farl tagather. This reant indicates that there was very Ifttie experfmentel error. 
COICIUSIOHS 
The results obtained in the experimental work of this thesis show substantial agreement with the postulated curves obtained by graphtcaliy combinding the procedures for betoh stean distillation and a Raoult law approximation of equilibrum curves. The benzene-bromobenzene system was checked at three different concentrations, and the benzene-toluene system at one. The latter, wioh follows Reoults" Iaw somewhat closer than the former, gave somerhat oloser correlation, but both syetems are suffiefently olose for general caloulation purposes. Hxamination of tenperature readings, observed and caloulated, showed a relatively constant disagreement wich indicated a deviation of each experimental and calculated regult but Ifkewise showed the accuracy of the experimental technique.

The general conolusion is that the procedure may be used as a close approxination for predicting distillates produced by batch steam distillation of binary mixtures, when the mixtures approximate Raoults" Iaw. The degree of error is dependent upon the degree of deviation from Raeults: Iaw, bat exact correlations have not been established. 
A P E I I X 


\section{SAMPIE CAJGULATIOIS}

After the oxperimental data for run no. 4 was obtafned the following calculations were made for each sample taken.

For sample number one the rolume of the $\mathrm{C}_{6} \mathrm{H} 6$ Iayer $=12.7$ ac. and has a composition of $6.0 \mathrm{~mol}$ percent ${ }^{6} \mathrm{G}_{5} \mathrm{Br}$. From Fig. 20 one can find that 6.0 mol percent $c_{6}{ }_{5} \mathrm{Br}=11.3 \mathrm{wt}$. percent $\mathrm{C}_{6}{ }_{5} \mathrm{Br}$. Prom FIg. 15 the specifio gravity $=0.920$

Wt. of eample $=12.7 \times 0.920=11.68 \mathrm{ems}$.

tt. of $06^{\mathrm{H}} 5^{\mathrm{Br}}$ in semple $=11.3 \times 11.68=$

1.230 s.

Lecumulative weight percent of bromobenzene

- Totel wt: of CGH $5 \mathrm{BP}$ distilled over

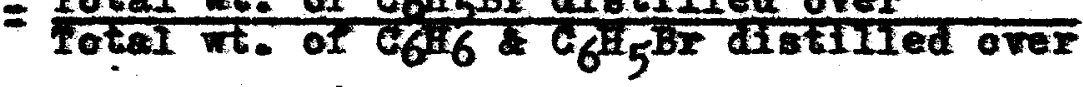

$=\frac{1.320}{11.68}=11.30$

Accumulative weight percent of benzene

$$
=100-11.3=88.7
$$

Accumulative rolume of samples = totel rolume of $\mathrm{C}_{6} \mathrm{H}_{6} \mathrm{C}_{6} \mathrm{H}_{5}^{\mathrm{Br}}$ distilled over $=12.7$

pereent total rolume distilled over

$=\frac{\text { Lecumalative rolume of gamples }}{\text { Total volum of original charg to pot }}$

$=\frac{12.7}{188}=6.76$ 


\section{SAMPLE CALCULATIONS (CONTIMURD)}

This procedure is repeated for each sample collected and then the percent voluwe is plotted ogafnet the composition of each sample.

sfter this the graphical resulto are calculated.

The orfiginal charge consisted of 188 ac. of $49 \mathrm{~mol}$ percent of $\mathrm{C}_{6}^{\mathrm{H}} 5^{\mathrm{Br}}$.

From Fig. 15 the spectefe gravity $=1.205$

$188 \times 1.205=226.5$ gme. of original chg.

$\frac{226.5 \times 0.66}{157.02}=0.954 \mathrm{mols} \mathrm{C}_{6}{ }^{\mathrm{H}}{ }^{\mathrm{Bx}}$

$\frac{226.5 \times 0.34}{78.11}=0.986 \mathrm{mols}_{6} \mathrm{C}_{6}$

$$
I_{1}=1.940 \text { mols total }
$$

$x_{1}=0.51=$ mol fraction of $c_{6}{ }_{6}$

Assume $x_{2}=0.45$

Rayleigh Equation $=$ In $\frac{L_{1}}{I_{2}}=\int_{x_{2}}^{x_{1}} \frac{d x}{y-x}$

The area under the curve in Fig. 7 between the

limit of 0.51 and $0.45=0.140$

$\operatorname{In} \frac{I .940}{I_{2}}=\int_{x_{2}}^{x_{1}} \frac{d x}{y-x}=0.140$

Solving, $I_{2}=1.687$ mols of residue

$I_{1}-I_{2}=1.490-1.687=0.253 \mathrm{mols}$ of distillate 
SAMPIS CALCULATIONS (CONTINUED)

Mols $\mathrm{C}_{6}^{\mathrm{H}} 6$ in residue $=1.687 \times 0.45=0.759$

Mols $\mathrm{C}_{6}^{\mathrm{H}} 5^{\mathrm{Br}}$ in residue $=1.687 \times 0.55=0.928$

Mols $C_{6}{ }_{6}$ in distillate $=0.986-0.759$

$$
=0.227
$$

Hols $\mathrm{C}_{6}^{\mathrm{H}} 5^{\mathrm{Br}}$ in distiriate $=0.954-0.928$

$$
=0.026
$$

Mol percent $C_{6}{ }^{\mathrm{H}} 5^{\mathrm{Br}}=\frac{0.026}{0.253}=10.28$

From Fig. $1510.28 \mathrm{~mol} \%=0.951 \mathrm{sp} . \mathrm{gr}$.

$0.227 \times 78.11=27.72 \mathrm{gms}$. of $\mathrm{c}_{6} \mathrm{H} 6$

$0.026 \times 157.02=4.08 \mathrm{gms}$. of $\mathrm{C}_{6} \mathrm{H}_{5} \mathrm{Br}$

Total $=21.80 \mathrm{gns}$. of distillate

$\frac{21.80}{0.951}=22.9 \mathrm{cos}$ of distillate

Percent total volume over $=\frac{22.9}{188}=12.2$

This procedure is repeated for various assumed values of $x_{2}$. From these values the curve in Fig. 9 for 51 mol percent starting composition is plotted. 
TABIE VI

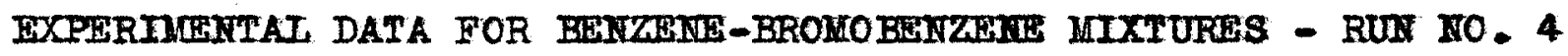

\begin{tabular}{|c|c|c|c|c|c|c|}
\hline $\begin{array}{l}\text { Somple } \\
\text { No. }\end{array}$ & $\begin{array}{l}\text { SampI } \\
\text { TotaI }\end{array}$ & $\begin{array}{l}\text { Volume } \\
\text { Water }\end{array}$ & $\begin{array}{l}c 0 . \\
c_{6}{ }_{6} \& C_{6} 5^{B r}\end{array}$ & $\begin{array}{l}{ }^{\circ} \mathrm{C} \\
\text { of Vapor }\end{array}$ & $\begin{array}{l}\text { Index of } \\
\text { Refraction }\end{array}$ & $\begin{array}{l}\text { HoI Percent } \\
\mathrm{C}_{6} \mathrm{H}_{5} \mathrm{Br}\end{array}$ \\
\hline 1 & 14.0 & 1.4 & 12.7 & 80.3 & 1.5020 & 6.0 \\
\hline 2 & 14.1 & 1.8 & 12.3 & 81.2 & 1.5035 & 8.0 \\
\hline 3 & 14.0 & 2.3 & 11.7 & 82.4 & 1.5044 & 9.4 \\
\hline 4 & 14.2 & 2.6 & 12.6 & 83.6 & 1.5058 & 12.8 \\
\hline 5 & 14.2 & 2.5 & 11.7 & 85.0 & 1.5077 & 14.0 \\
\hline 6 & 13.9 & 3.2 & 10.7 & 86.6 & 1.5102 & 18.1 \\
\hline 7 & 14.1 & $3 \cdot 5$ & 10.6 & 88.6 & 1.5141 & 24.2 \\
\hline 8 & 14.1 & $4 \cdot 3$ & 9.8 & 90.7 & 1.5208 & 34.6 \\
\hline 9 & 14.2 & 5.0 & 9.2 & 92.5 & 1.5291 & 48.3 \\
\hline 10 & 14.4 & 5.8 & 8.6 & 93.9 & 1.5378 & 63.3 \\
\hline 11 & 14.4 & 6.2 & 8.2 & 94.8 & 1.5462 & 78.4 \\
\hline Residue & 156.0 & 89.0 & 67.0 & - & 1.5568 & 98.9 \\
\hline Iginal Chg & 188.0 & - & 188.0 & - & 1.5295 & 49.0 \\
\hline
\end{tabular}




\section{TABLE VI (CONTINUED)}

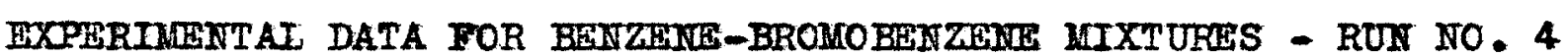

\begin{tabular}{|c|c|c|c|c|c|}
\hline $\begin{array}{l}\text { Sample } \\
\text { No. }\end{array}$ & $\begin{array}{l}\text { Wt. Percent } \\
\mathrm{C}_{6} \mathrm{H}_{5} \mathrm{Br}\end{array}$ & Density & $\begin{array}{l}\text { nt. of } \\
\text { Sample }\end{array}$ & $\begin{array}{l}\text { Wt. or } \\
{ }^{6} 6 \mathrm{H}^{\mathrm{H}} 5^{\mathrm{Br}}\end{array}$ & $\begin{array}{l}\text { Wt. Percent } \\
{ }^{C_{6}}{ }^{H}{ }^{B r} \text { Accum. }\end{array}$ \\
\hline 1 & 11.3 & 0.920 & 21.68 & 1.320 & 11.30 \\
\hline 2 & 15.0 & 0.935 & 11.50 & 1.725 & 13.17 \\
\hline 3 & $17 \cdot 3$ & 0.945 & 11.05 & 1.914 & 14.50 \\
\hline 4 & 20.5 & 0.959 & 11.11 & 2.280 & 15.95 \\
\hline 5 & 24.7 & 0.978 & 21.43 & 2.822 & 17.71 \\
\hline 6 & 30.8 & 1.005 & 10.77 & 3.320 & 19.77 \\
\hline 7 & 39.0 & 1.046 & 11.09 & 4.315 & 22.45 \\
\hline 8 & 51.5 & 1.114 & 10.90 & 5.610 & 26.00 \\
\hline 9 & $65 \cdot 5$ & 1.201 & 11.05 & 7.245 & 30.40 \\
\hline 10 & $77 \cdot 5$ & 1.291 & 11.10 & 8.610 & 35.05 \\
\hline 11 & 87.9 & 1.378 & 11.28 & 9.910 & 39.95 \\
\hline
\end{tabular}


TABIE VI (CONTINUED)

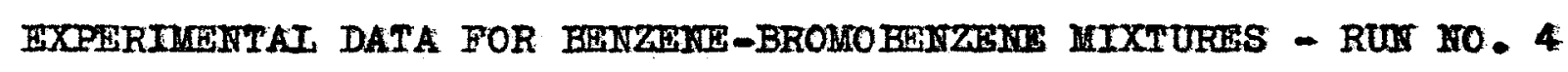

\begin{tabular}{|c|c|c|c|c|c|c|}
\hline $\begin{array}{l}\text { wt. Percent } \\
c_{6}{ }^{\mathrm{H}} 6 \text { Accum. }\end{array}$ & $\begin{array}{c}\text { Volume of } \\
\text { Samples Acoum }\end{array}$ & $\begin{array}{l}\text { Percent Total } \\
\text { Volwe over }\end{array}$ & $\begin{array}{r}\text { Obs. } \\
\text { Termp. }\end{array}$ & $\begin{array}{l}Y(\mathrm{Nol} \\
\left.\% \mathrm{C}_{6}^{\mathrm{H}} 6\right)\end{array}$ & $\begin{array}{l}x(\mathrm{NoI} \\
\left.\% \mathrm{C}_{6} \mathrm{H}_{6}\right)\end{array}$ & $\begin{array}{l}\text { Calculated } \\
\text { Temperature }\end{array}$ \\
\hline 88.70 & 12.7 & 6.76 & 80.3 & 94.0 & 59.0 & $77 \cdot 5$ \\
\hline 86.83 & 25.0 & 13.30 & 81.2 & 92.0 & 52.0 & 79.0 \\
\hline 85.50 & 36.7 & 19.50 & 82.4 & 90.6 & 48.0 & 80.2 \\
\hline 84.05 & 48.3 & 25.40 & 83.6 & 88.8 & 43.0 & 81.5 \\
\hline 82.29 & 60.0 & 31.90 & 85.0 & 86.0 & 36.0 & 83.5 \\
\hline 80.23 & 70.7 & 37.80 & 86.6 & 81.9 & 30.0 & 85.0 \\
\hline $77 \cdot 55$ & 81.3 & $43 \cdot 30$ & 88.6 & 75.8 & 23.8 & 86.7 \\
\hline 74.00 & 91.1 & 48.50 & 90.7 & 65.4 & 16.4 & $89 \cdot 3$ \\
\hline 69.60 & 100.3 & 53.40 & 92.5 & 51.7 & 10.7 & 21.0 \\
\hline 64.95 & 108.9 & 57.80 & 93.9 & 36.7 & 6.5 & 92.7 \\
\hline 60.05 & 117.1 & 62.40 & 94.8 & 21.6 & 3.6 & 93.7 \\
\hline
\end{tabular}


TABIE VII

CAICULATIONS FOR THE GRAPHICAI PROCEDURE USIUG BEMZRIUE-BROMOBETZEITE

WITH A STARTIUTG COMPOSITIOT OF $5 I$ MOL PIRGEMT

\begin{tabular}{lll|l|l|l|l|l|l}
$x_{2}$ & $x$ & $x_{1}$ & $I_{1}$ & $\int_{x_{2}}^{x_{1}} \frac{d x}{y-x}$ & $I_{2}$ & $I_{1}-I_{2}$ & $I_{2}(\mathrm{~A}) x_{2}$ & $I_{2}\left(100-x_{2}\right)$ \\
\hline 45 & 90.0 & 51 & 1.940 & 0.140 & 1.687 & 0.253 & 0.759 & 0.928 \\
40 & 88.1 & 51 & 1.940 & 0.247 & 1.518 & 0.422 & 0.606 & 0.912 \\
35 & 86.0 & 51 & 1.940 & 0.347 & 1.370 & 0.570 & 0.480 & 0.890 \\
30 & 83.0 & 51 & 1.940 & 0.442 & 1.246 & 0.694 & 0.374 & 0.872 \\
25 & 78.5 & 51 & 1.940 & 0.537 & 1.132 & 0.808 & 0.283 & 0.849 \\
20 & 73.0 & 51 & 1.940 & 0.631 & 1.030 & 0.910 & 0.206 & 0.824 \\
15 & 65.7 & 51 & 1.940 & 0.726 & 0.938 & 1.002 & 0.141 & 0.797 \\
10 & 57.0 & 51 & 1.940 & 0.828 & 0.846 & 1.094 & 0.085 & 0.761 \\
5 & 38.8 & 51 & 1.940 & 0.958 & 0.745 & 1.195 & 0.037 & 0.708 \\
2 & 21.0 & 51 & 1.940 & 1.083 & 0.655 & 1.285 & 0.013 & 0.642
\end{tabular}


TABIE VII (CONTINUED)

CALCULATIONS FOR THE GRAPHICAI PROCEDURE USING BENZRKE-BROMOBENZEITE WITH A STARTING COMPOSITION OF 51 NOL PERCENT

\begin{tabular}{|c|c|c|c|c|c|c|c|}
\hline $\begin{array}{c}(c) \\
0.986-A\end{array}$ & $\begin{array}{c}\text { (D) } \\
0.954-B\end{array}$ & $\frac{D}{I_{1}-I_{2}}$ & $a\left(7^{(\mathrm{E})}\right)$ & $\begin{array}{c}(F) \\
D(157.02)\end{array}$ & $\begin{array}{c}(G) \\
E^{(G)} F\end{array}$ & $\begin{array}{c}\text { (H) } \\
\mathrm{Sp} . \mathrm{Gr} .\end{array}$ & $\frac{G}{\mathbf{B}}$ \\
\hline 0.227 & 0.026 & 10.28 & 17.73 & 4.08 & 21.81 & 0.951 & 22.95 \\
\hline 0.380 & 0.042 & 9.95 & 29.70 & 6.60 & 36.30 & 0.949 & 38.30 \\
\hline 0.506 & 0.064 & 11.21 & 39.60 & 10.05 & 49.65 & 0.959 & 51.85 \\
\hline 0.612 & 0.082 & 11.81 & 47.90 & 12.90 & 60.80 & 0.961 & 63.80 \\
\hline 0.703 & 0.105 & 13.00 & 54.90 & 16.50 & 71.40 & 0.969 & 73.60 \\
\hline 0.780 & 0.130 & 14.30 & 60.90 & 20.40 & 81.30 & 0.979 & 83.00 \\
\hline 0.845 & 0.157 & 15.60 & 66.00 & 24.60 & 90.60 & 0.988 & 91.80 \\
\hline 0.901 & 0.193 & 17.60 & 70.50 & 30.30 & 100.80 & 1.001 & 100.70 \\
\hline 0.949 & 0.246 & 20.60 & 74.10 & 38.60 & 112.70 & 1.022 & 110.00 \\
\hline 0.973 & 0.312 & 24.20 & 76.00 & 49.00 & 125.00 & 1.047 & $119 \cdot 50$ \\
\hline
\end{tabular}


TABLE VII (CONTINURD)

CALCULATIONS FOR THE GRAPHICAL PROCEDURE USING BENZEIE-BROMOERWZEXEE WITH A STARTING COMPOSITION OF 51 HOL PERGENT

\begin{tabular}{c|c|c}
$\begin{array}{c}\text { Wt. Percent } \\
\text { C686 Aceum. }\end{array}$ & Volume of Samples & $\begin{array}{c}\text { Percent Volume } \\
\text { Orer }\end{array}$ \\
\hline 81.3 & 22.95 & 12.20 \\
81.8 & 38.30 & 20.35 \\
79.7 & 51.85 & 27.60 \\
78.8 & 63.20 & 33.60 \\
77.0 & 73.60 & 39.20 \\
75.0 & 83.00 & 44.10 \\
72.8 & 91.80 & 48.80 \\
70.0 & 100.70 & 53.60 \\
65.9 & 110.00 & 58.50 \\
60.7 & 119.50 & 63.60
\end{tabular}


TABIR VIII

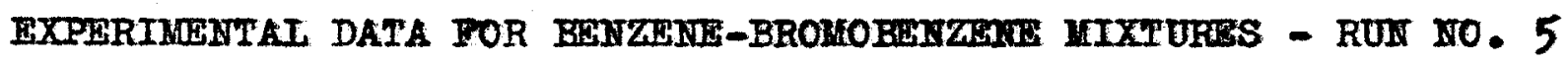

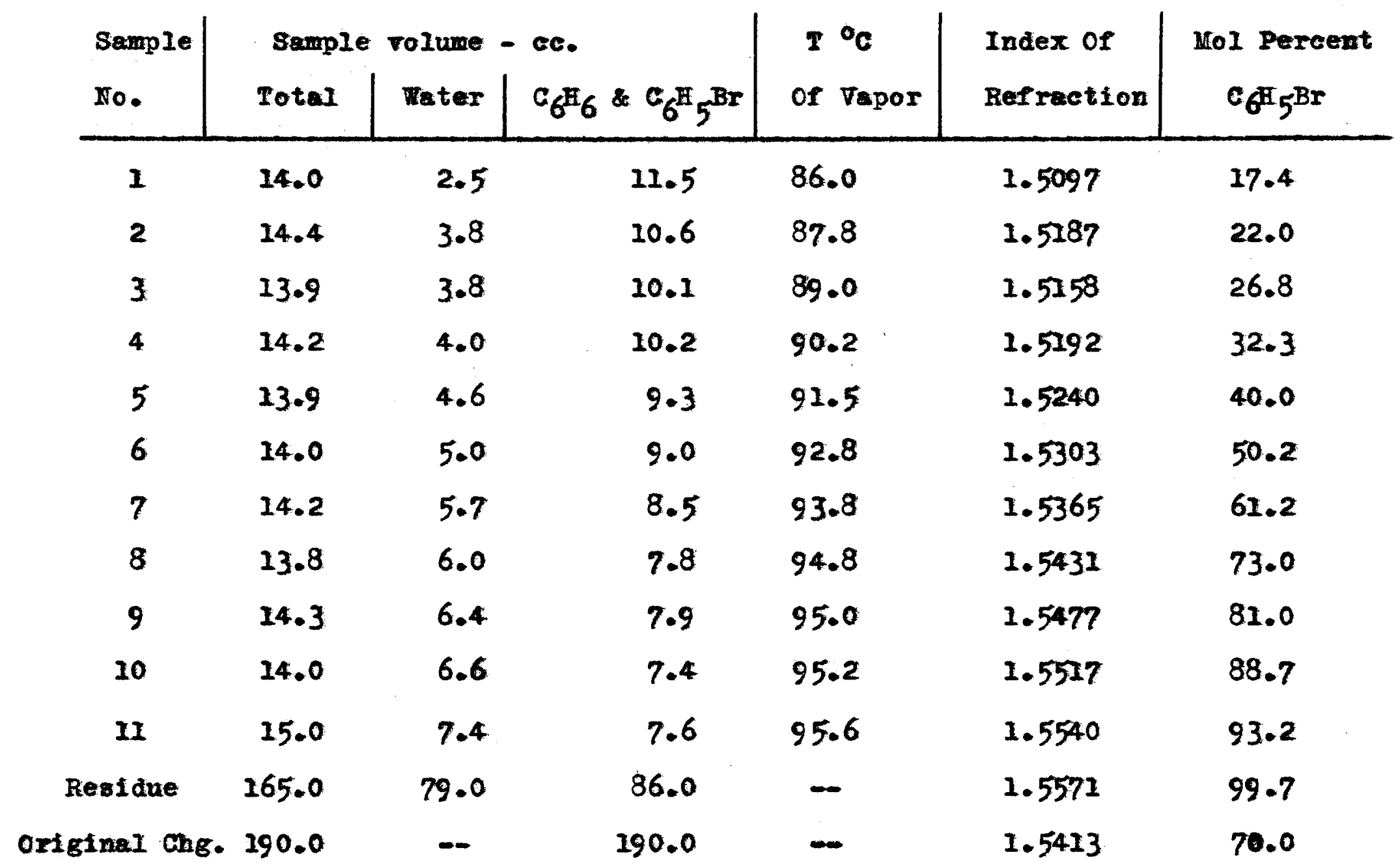




\section{TABIT VIII}

EXPERTDENTAL DATA FOR HENZEIIE-BRONOBENZETE MIXTURES - RUN HO. 5

\begin{tabular}{|c|c|c|c|c|c|}
\hline $\begin{array}{l}\text { Sample } \\
\text { No. }\end{array}$ & $\begin{array}{c}\text { Wt. Percent } \\
{ }_{6}{ }^{\mathrm{H}} 5^{\mathrm{Br}}\end{array}$ & Density & $\begin{array}{l}\text { Wt. of } \\
\text { sample }\end{array}$ & $\begin{array}{l}\text { Wt. or } \\
\mathrm{C}_{6} \mathrm{H}_{5} \mathrm{Br}\end{array}$ & $\begin{array}{l}\text { Wt. Percent } \\
{ }_{6} G^{\mathrm{B}} 5^{\mathrm{Br} \text { Accum. }}\end{array}$ \\
\hline 1 & 29.8 & 0.999 & 11.48 & 3.420 & 29.8 \\
\hline 2 & 36.0 & 1.030 & 10.91 & 3.930 & 32.8 \\
\hline 3 & 42.2 & 1.063 & 10.47 & 4.545 & 35.9 \\
\hline 4 & 49.0 & 1.098 & 11.20 & 5.490 & 39.2 \\
\hline 5 & $57 \cdot 3$ & 1.148 & 10.66 & 6.110 & 43.1 \\
\hline 6 & 67.1 & 1.213 & 10.91 & $7 \cdot 340$ & 46.9 \\
\hline 7 & 76.0 & 1.278 & 10.48 & 8.140 & 50.8 \\
\hline 8 & 84.2 & 1.348 & 10.48 & 8.820 & 54.8 \\
\hline 9 & 89.5 & 1.394 & 11.00 & 9.850 & 58.7 \\
\hline 10 & 94.0 & 1.436 & 10.60 & $9 \cdot 960$ & 62.3 \\
\hline 11 & 96.7 & 1.460 & 11.08 & 10.700 & 65.5 \\
\hline
\end{tabular}


TABIE VIII (COMTINUED)

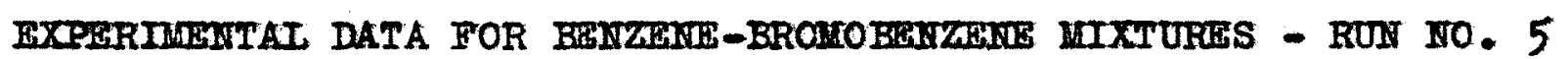

\begin{tabular}{|c|c|c|c|c|c|c|}
\hline $\begin{array}{c}\text { Volume of } \\
\text { Samples Accum. }\end{array}$ & $\begin{array}{l}\text { Wt. Percent } \\
C_{6}{ }_{6}{ }^{\text {Accum. }}\end{array}$ & $\begin{array}{l}\text { Percent Total } \\
\text { Volwwe Orer }\end{array}$ & $\begin{array}{l}\text { Obe. } \\
\text { Temp. }\end{array}$ & $\begin{array}{l}Y(\text { KOI } \\
\left.\% C_{6}^{\mathrm{E}} 6\right)\end{array}$ & $\begin{array}{l}x(\text { Nol } \\
\left.\% c_{6}{ }_{6}\right)\end{array}$ & $\begin{array}{l}\text { Calculated } \\
\text { remperature }\end{array}$ \\
\hline 11.5 & 70.2 & 6.05 & 86.0 & 82.6 & 31.0 & 84.6 \\
\hline 22.1 & 67.2 & II. 62 & 87.8 & 78.0 & 26.0 & 86.3 \\
\hline 32.2 & 64.1 & 16.95 & 89.0 & 73.2 & 21.4 & $87 \cdot 3$ \\
\hline 42.4 & 60.8 & $22 \cdot 30$ & 90.2 & 67.7 & 17.7 & 88.7 \\
\hline 51.7 & 56.9 & 27.20 & 91.5 & 60.0 & 13.8 & 90.0 \\
\hline 60.7 & 53.1 & 32.00 & 92.8 & 49.8 & 10.0 & 91.2 \\
\hline 69.2 & 49.2 & 36.40 & 93.8 & 38.8 & 7.0 & 92.5 \\
\hline 77.0 & 45.2 & 40.50 & 94.5 & 27.0 & 4.5 & 93.3 \\
\hline 84.9 & $4 I \cdot 3$ & 44.60 & 95.0 & 19.0 & 3.2 & 93.7 \\
\hline 92.3 & $37 \cdot 7$ & 48.50 & 95.2 & $11 \cdot 3$ & 2.0 & 94.5 \\
\hline 99.9 & 34.5 & 52.50 & 95.6 & 6.8 & 1.3 & 94.8 \\
\hline
\end{tabular}




\section{TABLE IX}

CALCULATIONS FOR THE GRAPHICAI PROCEDURE USITG BETZENE-BROMOBETZEITE WITH A STARTING CONPOSITION OF 30 MOL FERCENT

\begin{tabular}{l|l|l|l|l|l|l|l|l}
$X_{2}$ & $X$ & $x_{1}$ & $I_{1}$ & $x_{1} \frac{d x}{J-x}$ & $I_{2}$ & $I_{1}-I_{2}$ & $I_{2}(A) x_{2}$ & $\begin{array}{c}(B) \\
I_{2}\left(I 00-X_{2}\right)\end{array}$ \\
\hline 25 & 78.5 & 30 & 1.894 & 0.095 & 1.727 & 0.167 & 0.4320 & 1.295 \\
20 & 73.0 & 30 & 1.894 & 0.189 & 1.568 & 0.326 & 0.3135 & 1.255 \\
15 & 65.7 & 30 & 1.894 & 0.285 & 1.425 & 0.469 & 0.2140 & 1.811 \\
10 & 57.0 & 30 & 1.894 & 0.387 & 1.287 & 0.607 & 0.1237 & 1.158 \\
5 & 38.8 & 30 & 1.894 & 0.517 & 1.130 & 0.764 & 0.0565 & 1.074 \\
2 & 21.0 & 30 & 1.894 & 0.642 & 0.998 & 0.896 & 0.0199 & 0.978
\end{tabular}


TABLF IX (CONTINUED)

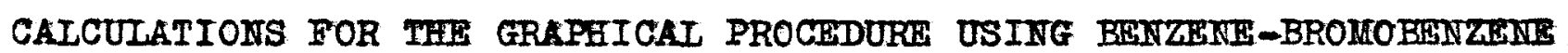
WITH A STARTING COMPOSITION OF 30 MOL PERCEAT

\begin{tabular}{|c|c|c|c|c|c|c|c|}
\hline $\begin{array}{c}(c) \\
0.574-8\end{array}$ & $\begin{array}{c}(D) \\
1.320-B\end{array}$ & $\frac{D}{I_{1}-I_{2}}$ & $c(78 . I I)$ & $\begin{array}{c}(F) \\
D(157.02)\end{array}$ & $\mathbf{E} \& F$ & Sp. Gr. & $\frac{G}{H}$ \\
\hline 0.142 & 0.025 & 14.95 & 11.10 & 3.95 & 15.03 & 0.982 & 15.05 \\
\hline 0.261 & 0.065 & 19.93 & 20.40 & 10.20 & 30.60 & 1.016 & 30.10 \\
\hline 0.360 & 0.109 & 23.25 & 28.15 & 17.10 & 45.25 & 1.040 & 43.50 \\
\hline 0.445 & 0.162 & 26.70 & 34.80 & 25.40 & 60.20 & 1.072 & 56.10 \\
\hline 0.518 & 0.246 & 32.40 & 40.50 & 38.60 & 79.10 & 1.098 & 72.20 \\
\hline 0.654 & 0.342 & 38.10 & 43.20 & 53.60 & 96.80 & 1.138 & 85.10 \\
\hline
\end{tabular}




\section{TABIE IX (CONTINUED)}

CAICULATIONS FOR THE GRAPHICAI PROCEDURR USING BENZENE-BROMOBENZENE WITH A STARTING COMPOSITION OF 30 MOL PERCENT

\begin{tabular}{|c|c|c|}
\hline $\begin{array}{l}\text { Volume of Semples } \\
\text { Accum. }\end{array}$ & $\begin{array}{l}\text { Wt. Percent } \\
{ }_{6}{ }_{6}{ }^{\mathrm{H}} \text { Accum. }\end{array}$ & $\begin{array}{c}\text { Percent Volume } \\
\text { Over }\end{array}$ \\
\hline 15.05 & 73.9 & 7.93 \\
\hline 30.10 & 66.7 & 15.84 \\
\hline 43.50 & 62.2 & 22.90 \\
\hline 56.10 & 57.7 & $29 \cdot 50$ \\
\hline 72.20 & 57.2 & 38.00 \\
\hline 85.10 & 44.7 & 44.80 \\
\hline
\end{tabular}




\section{TABLE $X$}

EXPFRIMENTAL DATA FOR BENZETEE-BROMOBENZEIUE MIXTURES RUN NO. 6

\begin{tabular}{|c|c|c|c|c|c|c|}
\hline $\begin{array}{l}\text { Sample } \\
\text { To. }\end{array}$ & $\begin{array}{l}\text { Sample } \\
\text { Total }\end{array}$ & $\begin{array}{l}\text { Volume } \\
\text { Veter }\end{array}$ & $\mathrm{c}_{6}{ }_{6}: \mathrm{c}_{6}{ }^{\mathrm{H}}{ }^{\mathrm{Br}}$ & $\begin{array}{l}T{ }^{\circ} \mathrm{C} \\
\text { Vapor }\end{array}$ & $\begin{array}{l}\text { Index of } \\
\text { Refraction }\end{array}$ & $\begin{array}{l}\text { Mol \% } \\
{ }^{\mathrm{C}} 6^{\mathrm{H}} 5^{\mathrm{Br}}\end{array}$ \\
\hline$I$ & 13.9 & 0.9 & 13.0 & 75.8 & 1.4995 & 2.4 \\
\hline 2 & 13.9 & 1.2 & 12.7 & 76.3 & $1 \cdot 5001$ & $3 \cdot 3$ \\
\hline 3 & 13.5 & 1.4 & 12.1 & 76.8 & 1.5007 & 4.0 \\
\hline 4 & 13.6 & 1.6 & 12.0 & $77 \cdot 5$ & 1.5009 & $4 \cdot 3$ \\
\hline 5 & 15.0 & 1.8 & 13.2 & 78.2 & 1.5011 & 4.8 \\
\hline 6 & 24.1 & 1.9 & 12.2 & 79.1 & 1.5019 & 5.7 \\
\hline 7 & 14.4 & 2.2 & 12.2 & 80.3 & 1.5029 & 7.0 \\
\hline 8 & 14.8 & 2.5 & 12.3 & 81.8 & 1.5040 & 8.8 \\
\hline 9 & 13.7 & 2.2 & 11.5 & 83.7 & 1.5060 & 11.5 \\
\hline 10 & 14.0 & 2.8 & 11.2 & 85.8 & 1.5084 & $15 \cdot 3$ \\
\hline 11 & 14.0 & 3.8 & 10.2 & 88.7 & 1.5137 & 23.4 \\
\hline 12 & 14.1 & $4 \cdot 5$ & 9.6 & 91.3 & 1.5232 & 38.8 \\
\hline 13 & 14.5 & 5.7 & 8.8 & 94.0 & 1.5370 & 62.1 \\
\hline 14 & 14.8 & 7.0 & 7.8 & 95.3 & 1.5510 & 87.4 \\
\hline Resi due & 141.0 & 105.0 & 36.0 & $-\infty$ & 1.5573 & 99.9 \\
\hline $\begin{array}{l}\text { Original } \\
\text { Chg. }\end{array}$ & 198.0 & $-\cdots$ & 198.0 & - & 1.5178 & 30.0 \\
\hline
\end{tabular}


TABIE $X$ (CONTINUED)

EXPERTMENTAI DATA FOR BEIZERE-BROMOBENZENE MIXTURES RUN NO. 6

\begin{tabular}{|c|c|c|c|c|c|}
\hline $\begin{array}{l}\text { Sample } \\
\text { No. }\end{array}$ & $\begin{array}{l}\mathrm{Wt}_{*} \% \\
\mathrm{C}_{6^{\mathrm{H}}}{ }^{\mathrm{Br}}\end{array}$ & Density & $\begin{array}{l}\text { Wt. of } \\
\text { Sample }\end{array}$ & $\begin{array}{l}\text { Wt. of } \\
\mathrm{C}_{6} \mathrm{H}_{5}^{\mathrm{Br}}\end{array}$ & $\begin{array}{c}\text { wt. } \$ \mathrm{c}_{6}^{\mathrm{F}} 5^{\mathrm{Br}} \\
\text { Accum. }\end{array}$ \\
\hline 1 & 5.0 & 0.894 & 11.6 & 0.580 & 5.0 \\
\hline 2 & 6.8 & 0.900 & 11.4 & 0.775 & 5.9 \\
\hline 3 & $7 \cdot 9$ & 0.906 & 11.0 & 0.870 & 6.5 \\
\hline 4 & 8.6 & 0.909 & 10.9 & 0.937 & 7.1 \\
\hline 5 & 9.3 & 0.919 & 12.0 & 1.115 & $7 \cdot 5$ \\
\hline 6 & 10.9 & 0.918. & 11.2 & 1.221 & 8.1 \\
\hline 7 & 13.2 & 0.927 & 11.3 & 1.492 & 8.8 \\
\hline 8 & 16.3 & 0.940 & 11.5 & 1.875 & 9.8 \\
\hline 9 & 20.9 & 0.959 & 11.0 & 2.300 & 11.0 \\
\hline 10 & 26.8 & 0.985 & 11.0 & 2.946 & 12.5 \\
\hline$I I$ & 38.0 & 1.041 & 10.6 & 4.030 & 14.7 \\
\hline 12 & 56.0 & 1.141 & 10.9 & 6.100 & 18.0 \\
\hline 13 & 76.8 & 1.283 & 11.3 & 8.680 & 22.6 \\
\hline 14 & 93.4 & 1.429 & 11.1 . & 10.350 & 27.6 \\
\hline
\end{tabular}


TABLE $X$ (CONT INUED)

EXXPERTMENTAI DATA FOR BETZZRRE-BROMOBETZFNE MIXTURES RUN NO. 6

\begin{tabular}{|c|c|c|c|c|c|c|}
\hline $\begin{array}{l}\text { VoIume of } \\
\text { Samples } \\
\text { Accum. }\end{array}$ & $\begin{array}{l}\text { Wt. \% } \\
\text { C6I } 6^{\mathbb{E} 6} \\
\text { Accim. }\end{array}$ & $\begin{array}{l}\text { \% Total } \\
\text { Volume } \\
\text { Orer }\end{array}$ & $\begin{array}{l}\text { Obs. } \\
\text { Temp. }\end{array}$ & $\begin{array}{l}\mathrm{Y}(\mathrm{MOI} \\
\left.\% \mathrm{C}_{6}^{\mathrm{H}} 6\right)\end{array}$ & 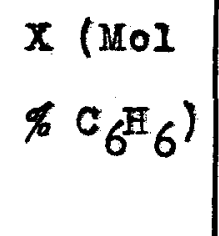 & $\begin{array}{l}\text { Calcul- } \\
\text { ated } \\
\text { Temp. }\end{array}$ \\
\hline 13.0 & 95.0 & 6.56 & 75.8 & 97.6 & 78.0 & 73.3 \\
\hline 25.7 & 94.1 & 12.98 & 76.3 & 96.7 & 71.0 & 74.7 \\
\hline 37.8 & 93.5 & 19.09 & 76.8 & 96.0 & 67.0 & $75 \cdot 5$ \\
\hline 49.8 & 92.9 & 25.10 & $77 \cdot 5$ & 95.7 & 65.8 & 75.8 \\
\hline 63.0 & 22.5 & 31.80 & 78.2 & 95.2 & 63.5 & 76.2 \\
\hline 75.2 & 91.9 & 38.00 & 79.1 & 94.3 & 60.5 & 76.9 \\
\hline 87.4 & 91.2 & 44.10 & 80.3 & 93.0 & 55.5 & $78 \cdot 3$ \\
\hline 99.7 & 90.2 & 50.40 & 81.8 & 91.2 & 50.0 & $79 \cdot 5$ \\
\hline 111.2 & 89.0 & 56.10 & 83.7 & 88.5 & 42.4 & 81.5 \\
\hline 122.4 & 87.5 & 61.80 & 85.8 & 84.7 & 33.9 & 83.8 \\
\hline 132.6 & 85.3 & 67.00 & 88.7 & 76.6 & 24.4 & 86.7 \\
\hline 142.2 & 82.0 & 71.90 & 91.3 & 61.2 & 14.4 & 90.0 \\
\hline 151.0 & 77.4 & 76.30 & 94.0 & 37.9 & 6.8 & 93.3 \\
\hline 158.8 & 72.4 & 80.20 & 95.3 & 12.6 & 2.2 & 94.5 \\
\hline
\end{tabular}


TABTE XI

CAICULATIONS FOR THE GRAPHICAI PROCEDURE USING BEIZENE-BROMOBENZFIVE MIXTURES WITH A STARTING COMPOSITION OF 70 NOL PERCENT

\begin{tabular}{r|lll|l|l|l|l|l}
$x_{2}$ & $x$ & $x_{1}$ & $I_{1}$ & $\int_{x_{2}}^{x_{1}} \frac{d x}{y-x}$ & $I_{2}$ & $I_{1}-I_{2}$ & $I_{2}^{(A)} x_{2}$ & $I_{2}\left(100-x_{2}\right)$ \\
\hline 65 & 95.6 & 70 & 2.110 & 0.174 & 1.772 & 0.338 & 1.150 & 0.622 \\
60 & 94.5 & 70 & 2.110 & 0.327 & 1.520 & 0.590 & 0.912 & 0.608 \\
50 & 91.7 & 70 & 2.110 & 0.590 & 1.160 & 0.950 & 0.530 & 0.580 \\
40 & 88.2 & 70 & 2.110 & 0.812 & 0.936 & 1.174 & 0.375 & 0.561 \\
30 & 83.0 & 70 & 2.110 & 1.007 & 0.724 & 1.386 & 0.217 & 0.507 \\
25 & 78.5 & 70 & 2.110 & 1.202 & 0.633 & 1.477 & 0.158 & 0.475 \\
20 & 73.0 & 70 & 2.110 & 1.296 & 0.576 & 1.534 & 0.115 & 0.461 \\
15 & 65.7 & 70 & 2.110 & 1.392 & 0.523 & 1.587 & 0.078 & 0.445 \\
10 & 57.0 & 70 & 2.110 & 1.494 & 0.473 & 1.673 & 0.047 & 0.426 \\
5 & 38.9 & 70 & 2.110 & 1.623 & 0.415 & 1.695 & 0.021 & 0.394 \\
2 & 21.0 & 70 & 2.110 & 1.724 & 0.368 & 1.742 & 0.007 & 0.361
\end{tabular}


TABLE XI (CONTINUED)

CALCULATIONS FOR THE GRAPHICAI PROCEDURE USING BEIZZEWE-BROHOBETZENES MIXTURES WITH A STARTING COMPOSITION OF 70 MOL PERCEIT

\begin{tabular}{|c|c|c|c|c|c|c|c|}
\hline $\begin{array}{c}(C) \\
0.574-A\end{array}$ & $\begin{array}{c}\text { (D) } \\
1.320-B\end{array}$ & $\frac{D}{I_{1}-I_{2}}$ & $\begin{array}{c}(\mathrm{E}) \\
a(78.11)\end{array}$ & $\begin{array}{c}(F) \\
D(157.02)\end{array}$ & $\begin{array}{c}(G) \\
E \& F\end{array}$ & $\begin{array}{c}(H) \\
\mathrm{sp} \cdot \mathrm{Gr}\end{array}$ & $\frac{G}{H}$ \\
\hline 0.328 & 0.010 & 2.9 & 25.6 & 1.6 & $27 \cdot 2$ & 0.897 & 30.0 \\
\hline 0.566 & 0.024 & 4.1 & $44 \cdot 3$ & 3.8 & 48.1 & 0.906 & 53.1 \\
\hline 0.898 & 0.052 & 5.5 & 70.1 & 8.2 & 78.3 & 0.917 & 85.4 \\
\hline 1.103 & 0.071 & 6.0 & 86.3 & 11.1 & 97.4 & 0.920 & 105.7 \\
\hline 1.261 & 0.125 & 9.0 & 98.6 & 19.6 & 118.2 & 0.941 & 125.8 \\
\hline 1.320 & 0.157 & 10.6 & 103.1 & 24.7 & 127.8 & 0.953 & 134.1 \\
\hline 1.363 & 0.171 & 11.1 & 106.5 & 26.9 & 133.4 & 0.958 & $139 \cdot 3$ \\
\hline 1.400 & 0.187 & 11.8 & $109 \cdot 3$ & 29.4 & 138.7 & 0.961 & 144.1 \\
\hline 1.431 & 0.206 & 12.6 & 112.0 & 32.4 & 144.4 & 0.967 & $149 \cdot 5$ \\
\hline 1.457 & 0.238 & 14.0 & 113.8 & 37.4 & 151.2 & 0.977 & 155.0 \\
\hline 1.471 & 0.271 & 15.5 & 115.0 & 42.6 & 157.6 & 0.988 & 159.8 \\
\hline
\end{tabular}


TABLE XI (CONTINUED)

CAICULATIONS FOR THE GRAPHICAI PROCEDURR USTHG BENZEHTE-BROMOBETZENIS MIXTURES WITH A STARTING COMPOSITTON OF 70 MOL PIRRGENT

\begin{tabular}{|c|c|c|}
\hline $\begin{array}{c}\text { Volume of Samples } \\
\text { secum. }\end{array}$ & $\begin{array}{l}\text { Wt. Percent } \\
C_{6}{ }^{\mathrm{H}} 6 \text { Accum. }\end{array}$ & $\begin{array}{c}\text { Percent Volume } \\
\text { Orer }\end{array}$ \\
\hline 30.3 & 94.1 & 15.3 \\
\hline 53.1 & 92.0 & 26.8 \\
\hline 85.4 & 89.6 & 43.1 \\
\hline 105.7 & 88.6 & 53.4 \\
\hline 125.8 & 83.5 & 63.5 \\
\hline 134.1 & 80.7 & 67.9 \\
\hline 139.3 & 79.8 & 70.4 \\
\hline 144.1 & 78.9 & 72.9 \\
\hline 149.5 & 77.6 & 75.5 \\
\hline 155.0 & 75.1 & 78.3 \\
\hline 159.8 & 73.0 & 80.6 \\
\hline
\end{tabular}


TABIE XII

DERIVED DATA FROM THE CONSTRUCTED TEMPERATURE PRESSURE CURVE FOR BENZENE, TOIUENE, AND WATER

\begin{tabular}{|c|c|c|c|}
\hline $\mathrm{x}$ & $\mathrm{T}^{0} \mathrm{C}$ & $p_{\mathrm{C}_{6} \mathrm{H}_{6}} \mathrm{p}_{\mathrm{C}_{6}{ }^{\mathrm{H}} 5^{\mathrm{Br}}}$ & $P_{0}$ of $C_{6}{ }_{5} \mathrm{Br}$ \\
\hline 100 & 69.2 & 532 & 0 \\
\hline 90 & 70.4 & 521 & 22 \\
\hline 80 & 71.7 & 508 & 45 \\
\hline 70 & 73.0 & 492 & 70 \\
\hline 60 & $74 \cdot 5$ & 478 & 97 \\
\hline 50 & 76.0 & 459 & 128 \\
\hline 45 & 76.8 & 449 & 145 \\
\hline 40 & $77 \cdot 6$ & 439 & 162 \\
\hline 35 & 78.4 & 429 & 181 \\
\hline 30 & 79.0 & 419 & 199 \\
\hline 25 & $79 \cdot 9$ & 406 & 218 \\
\hline 20 & 80.7 & 393 & 238 \\
\hline 15 & 81.6 & 379 & 262 \\
\hline 10 & 82.5 & 366 & 288 \\
\hline 5 & $83 \cdot 5$ & 350 & 308 \\
\hline 2 & 84.1 & 341 & 329 \\
\hline 0 & 84.4 & 337 & 337 \\
\hline
\end{tabular}


TABIE XII (CONTINUED)

DERIVED DATA FROM THE CONSTRUCTED TEMPERATURE PRESSURE CURVI FOR BETZENE, TOLUENE, AND WATER

\begin{tabular}{|c|c|c|c|}
\hline$P_{0}$ of $C_{6} G^{H}$ & $Y$ & $Y-X$ & $\frac{1}{Y-x}$ \\
\hline 532 & 100.0 & 0.000 & $\infty$ \\
\hline 499 & 95.6 & 0.056 & 17.85 \\
\hline 463 & 91.2 & 0.112 & 8.44 \\
\hline 422 & 85.8 & 0.158 & 6.33 \\
\hline 381 & 79.8 & 0.198 & 5.05 \\
\hline 331 & 72.2 & 0.222 & 4.50 \\
\hline 304 & 67.8 & 0.228 & 4.39 \\
\hline 277 & 63.1 & 0.231 & 4.34 \\
\hline 248 & $57 \cdot 9$ & 0.229 & $4 \cdot 39$ \\
\hline 220 & 52.6 & 0.226 & 4.43 \\
\hline 188 & 46.2 & 0.212 & 4.72 \\
\hline 155 & 39.4 & 0.194 & 5.15 \\
\hline 117 & 30.8 & 0.158 & $6 \cdot 34$ \\
\hline 78 & 21.3 & 0.113 & 8.85 \\
\hline 42 & 12.0 & 0.070 & $14 \cdot 30$ \\
\hline 12 & $3 \cdot 5$ & 0.015 & 66.60 \\
\hline 0 & 0.0 & 0.000 & $\infty$ \\
\hline
\end{tabular}




\section{TABLE XIII}

EXPERTMENTAL DATA FOR BENZENE-TOLUENE MIXTURES RUN NO. 7

\begin{tabular}{|c|c|c|c|c|c|c|}
\hline $\begin{array}{l}\text { Sample } \\
\text { No. }\end{array}$ & $\begin{array}{r}\text { Samp } \\
\text { Total }\end{array}$ & $\begin{array}{l}\text { Ie Volu } \\
\text { Water }\end{array}$ & $\begin{array}{l}c_{6}{ }^{\mathrm{H}}{ }^{*} \mathrm{C}_{7}^{\mathrm{H}} 8 \\
\end{array}$ & $\begin{array}{l}\text { Vapor } \\
T \\
{ }^{\circ} \mathrm{C}\end{array}$ & $\begin{array}{l}\text { Index of } \\
\text { Refraction }\end{array}$ & $\begin{array}{l}\text { Mol \% } \\
\mathrm{C}_{6}{ }_{6}^{\mathrm{H}}\end{array}$ \\
\hline 1 & 14.0 & 1.0 & 13.0 & 76.3 & 1.4956 & 70.0 \\
\hline 2 & $14 \cdot 3$ & 1.4 & 12.9 & 76.9 & 1.4955 & 68.3 \\
\hline 3 & 14.0 & 1.7 & 12.3 & $77 \cdot 2$ & 1.4954 & 66.6 \\
\hline 4 & 14.0 & 1.6 & 12.4 & 77.8 & 1.4953 & 65.0 \\
\hline 5 & 14.1 & 1.6 & 12.5 & 78.0 & 1.4950 & $59 \cdot 5$ \\
\hline 6 & 14.5 & 2.0 & 12.5 & 78.4 & 1.4950 & $59 \cdot 5$ \\
\hline 7 & 14.7 & 1.7 & 13.0 & 79.0 & 1.4949 & $57 \cdot 9$ \\
\hline 8 & 14.6 & 2.0 & 12.6 & $79 \cdot 5$ & 1.4947 & 53.6 \\
\hline 9 & 14.4 & 2.0 & 12.4 & 80.1 & $I .4946$ & 51.2 \\
\hline 10 & 14.2 & 2.2 & 12.0 & 80.3 & 1.4945 & 48.8 \\
\hline 11 & 14.2 & 2.2 & 12.0 & 80.9 & 1.4943 & 42.9 \\
\hline 12 & 14.2 & 2.5 & 11.7 & 82.5 & 1.4941 & 35.0 \\
\hline 13 & 14.4 & 2.5 & 11.9 & 83.0 & 1.4939 & 24.5 \\
\hline 14 & 14.3 & 2.2 & 12.1 & 83.3 & 1.4937 & 12.5 \\
\hline 15 & 14.1 & 2.6 & 11.5 & 84.3 & 1.4935 & 0.0 \\
\hline 16 & 14.2 & 11.0 & 3.2 & 100.0 & 1.4935 & 0.0 \\
\hline $\begin{array}{l}\text { Orig. } \\
\text { Ong. }\end{array}$ & 197.0 & $-\infty$ & 197.0 & $-\infty$ & 1.4945 & 48.8 \\
\hline
\end{tabular}


TABLE XII (COMPRUED)

EXPFRIUENTAI DATA POR BENZETE-TOLURWE MIXTURES RUN No. 7

\begin{tabular}{|c|c|c|c|c|c|}
\hline $\begin{array}{l}\text { Sample } \\
\text { Ho. }\end{array}$ & $\begin{array}{l}\text { wt. } \% \\
0_{7} \mathrm{H}_{8}\end{array}$ & Density & $\begin{array}{l}\text { Wt. of } \\
\text { sample }\end{array}$ & $\begin{array}{l}\text { Dt. of } \\
\mathrm{G}_{7} \mathrm{H}_{8}\end{array}$ & $\begin{array}{c}\text { wt. } \% \mathrm{C}_{7}{ }^{\mathrm{H}} 8 \\
\text { Accoum. }\end{array}$ \\
\hline$I$ & 33.5 & 0.8690 & $11 \cdot 30$ & 3.782 & $33 \cdot 5$ \\
\hline 2 & 35.2 & 0.8687 & 11.20 & 3.940 & 34.3 \\
\hline 3 & $37 \cdot 3$ & 0.8685 & 10.68 & 3.985 & 35.3 \\
\hline 4 & 38.8 & 0.8682 & 10.75 & 4.175 & 36.2 \\
\hline 5 & 44.5 & 0.8673 & 10.82 & 4.815 & 37.8 \\
\hline 6 & 44.5 & 0.8673 & 10.82 & 4.815 & 38.9 \\
\hline 7 & 46.2 & 0.8671 & 11.28 & 5.210 & 40.0 \\
\hline 8 & 50.3 & 0.8664 & 10.92 & 5.500 & 41.3 \\
\hline 9 & 52.8 & 0.8661 & 10.75 & 5.680 & 42.5 \\
\hline 10 & 55.5 & 0.8658 & 10.40 & 5.775 & 43.8 \\
\hline$I I$ & 61.0 & 0.8650 & 10.58 & 6.330 & 45.2 \\
\hline 12 & 68.5 & 0.8641 & 10.10 & 6.910 & 47.0 \\
\hline 13 & 78.5 & 0.8629 & 10.26 & 8.050 & 49.4 \\
\hline 14 & 89.4 & 0.8617 & 10.42 & $9 \cdot 310$ & 52.1 \\
\hline 15 & 100.0 & 0.8605 & 9.90 & 9.900 & 55.1 \\
\hline 16 & 100.0 & 0.8605 & 2.75 & 2.750 & 55.8 \\
\hline
\end{tabular}


TABLF XII (CONTINUED)

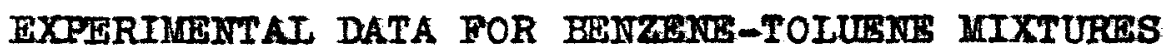

RUN NO. 7

\begin{tabular}{|c|c|c|c|c|c|c|}
\hline $\begin{array}{l}\text { Volume of } \\
\text { Semples } \\
\text { Accum. }\end{array}$ & $\begin{array}{l}\text { Wt. \% } \\
\text { VoIume } \\
\text { Accum. }\end{array}$ & $\begin{array}{l}\text { Totel } \\
\text { Volume } \\
\text { Over }\end{array}$ & $\begin{array}{l}\text { Obs. } \\
\text { Temp. } \\
{ }^{\circ} \mathrm{C}\end{array}$ & $\begin{array}{l}Y(\mathrm{Mol} \\
\left.\% \mathrm{C}_{6} \mathrm{H}_{6}\right)\end{array}$ & $\begin{array}{l}x(\mathrm{MOI} \\
\left.\% \mathrm{C}_{6} \mathrm{H}_{6}\right)\end{array}$ & $\begin{array}{l}\text { Cal. } \\
\text { Temp. } \\
{ }^{\circ} \mathrm{C}\end{array}$ \\
\hline 13.0 & 66.5 & 6.6 & 76.3 & 70.0 & $47 \cdot 4$ & 76.5 \\
\hline 25.9 & 65.7 & 13.1 & 76.9 & 68.3 & 45.2 & 76.7 \\
\hline 38.2 & 64.7 & 19.4 & $77 \cdot 2$ & 66.6 & 43.3 & 77.2 \\
\hline 50.6 & 63.8 & 25.7 & 77.8 & 65.0 & 41.8 & 77.4 \\
\hline 63.1 & 62.2 & 32.1 & 78.0 & $59 \cdot 5$ & 36.0 & 78.3 \\
\hline 75.6 & 61.1 & 38.4 & 78.4 & $59 \cdot 5$ & 36.0 & 78.3 \\
\hline 88.6 & 60.0 & 45.0 & 79.0 & 57.9 & 34.4 & 78.5 \\
\hline 101.2 & 58.7 & 51.4 & $79 \cdot 5$ & 53.6 & 30.5 & 79.0 \\
\hline 113.6 & $57 \cdot 5$ & 57.6 & 80.1 & 51.2 & 28.7 & 79.4 \\
\hline 125.6 & 56.2 & 63.8 & 80.4 & 48.8 & 26.5 & 79.6 \\
\hline 137.6 & 54.8 & 69.9 & 80.9 & 42.9 & 22.1 & 80.3 \\
\hline $149 \cdot 3$ & 53.0 & 75.9 & 82.5 & 35.0 & 17.1 & 81.3 \\
\hline 161.2 & 50.6 & 82.7 & 83.0 & 24.5 & 11.2 & 82.2 \\
\hline 173.3 & 47.9 & 88.1 & 83.3 & 12.5 & 5.0 & 83.5 \\
\hline 184.8 & 44.9 & 93.8 & $84 \cdot 3$ & 0.0 & 0.0 & 84.4 \\
\hline 188.0 & 44.2 & 95.5 & 100.0 & 0.0 & 0.0 & 84.4 \\
\hline
\end{tabular}




\section{TABIE XIV}

CAICUIATIONS FOR THE GRAFHICAL PROGEDURE USING BENZANE-TOLUEIT MIXIURES WITH A STARTING COMPOSITION OF 48.8 MOL PHRCAIT

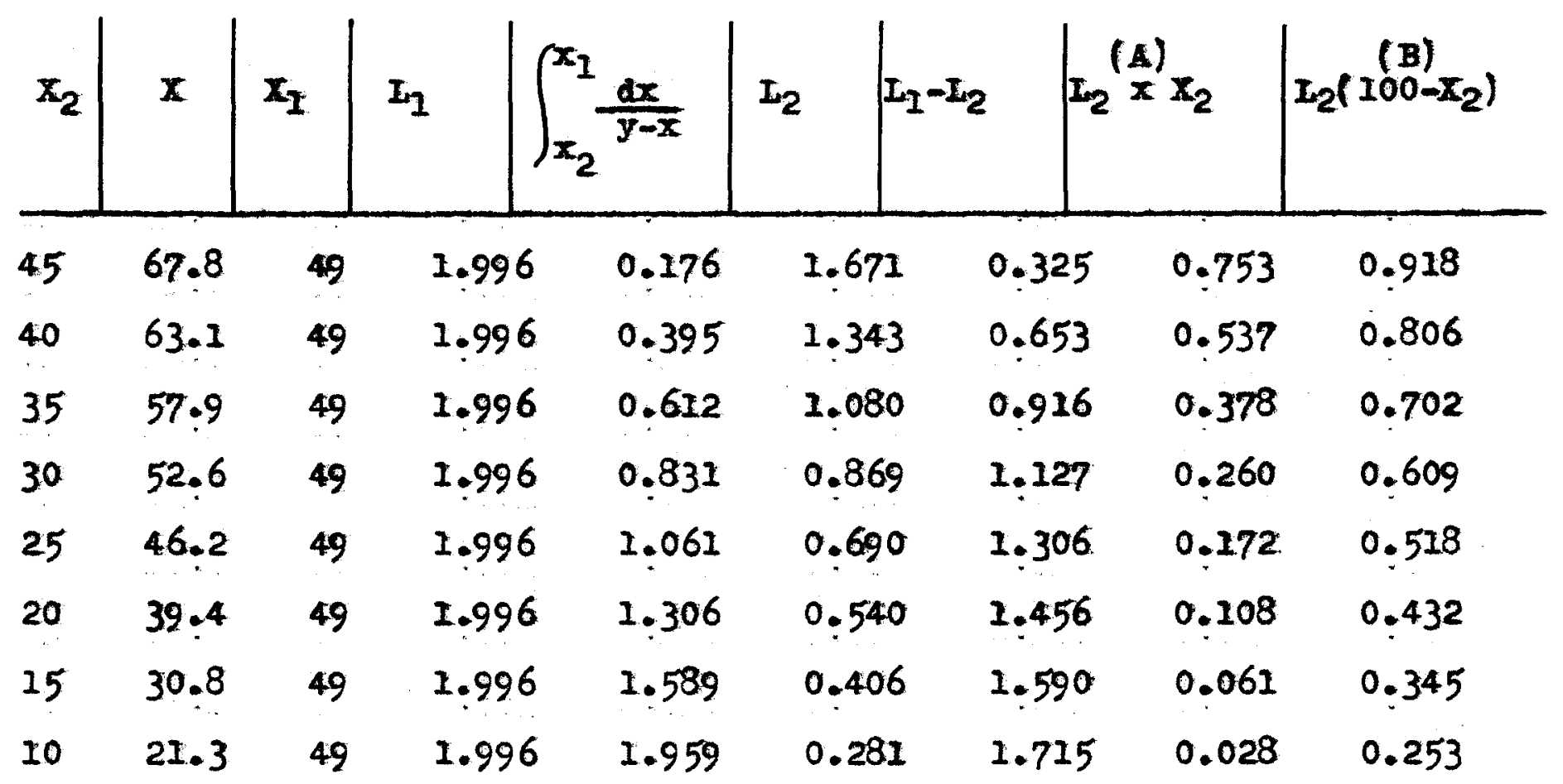




\section{TABLE XIV (CONTINURE)}

CALCULATIONS OF THE GRAPHICAL PROCEDURE USING BRAZRER-TOLUBNE NIXTURES WITH A STARTING CONPOSITION OF 48.8 MOI PBRCENT

\begin{tabular}{|c|c|c|c|c|c|c|c|}
\hline $\begin{array}{c}(c) \\
0.987-A\end{array}$ & $\begin{array}{c}(D) \\
1.018-B\end{array}$ & $\frac{D}{I_{1}-I_{2}}$ & of $7^{(3.11)}$ & $D(157.02)$ & $\begin{array}{c}(a) \\
\mathrm{E} \& \mathrm{~F}\end{array}$ & $\begin{array}{c}\text { (H) } \\
\text { Sp. Gr. }\end{array}$ & $\frac{G}{H}$ \\
\hline 0.225 & 0.100 & 30.8 & 17.60 & 9.21 & 26.81 & 0.8636 & 31.1 \\
\hline $0.44 I$ & 0.212 & 32.5 & 34.55 & $19 \cdot 54$ & 54.09 & 0.8638 & 62.6 \\
\hline 0.600 & 0.316 & 34.5 & 46.95 & 29.15 & 76.10 & 0.8641 & 88.1 \\
\hline 0.718 & 0.409 & 36.3 & 56.10 & 37.65 & 93.75 & 0.8643 & 108.5 \\
\hline 0.806 & 0.500 & $38 \cdot 3$ & 63.00 & 46.10 & 109.10 & 0.8645 & 126.5 \\
\hline 0.870 & 0.586 & 40.3 & 68.00 & 54.05 & 122.50 & 0.8647 & 142.0 \\
\hline 0.917 & 0.673 & 42.3 & 71.70 & 62.00 & 133.70 & 0.8649 & 154.9 \\
\hline 0.950 & 0.765 & 44.5 & $74 \cdot 30$ & 70.50 & 144.80 & 0.8652 & 167.1 \\
\hline
\end{tabular}


TABLE XIV (CONTINUED)

CALCULATIONS OF THE GRAPHICAL PROCEDURE USING BENZRERE-TOLOENE VIXTURRS WITH A STARTING COMPOSITION OF 48.8 MOL PERCEINT

\begin{tabular}{c|c|c}
$\begin{array}{c}\text { Volume of Samples } \\
\text { Accum. }\end{array}$ & $\begin{array}{c}\text { mt. Percent } \\
C_{6}^{\mathrm{H}} 6 \text { Accum. }\end{array}$ & $\begin{array}{c}\text { Percent Volume } \\
\text { Over }\end{array}$ \\
\hline 31.1 & 65.6 & 15.87 \\
62.6 & 63.7 & 31.80 \\
88.1 & 61.5 & 44.70 \\
108.5 & 59.9 & 55.00 \\
126.5 & 57.6 & 64.20 \\
142.0 & 55.5 & 72.10 \\
154.9 & 53.6 & 78.60 \\
167.1 & 51.3 & 85.00
\end{tabular}


BIBLOGRAPH $Y$ 
(1) Rayleigh, Phil. Lag. 8, 534 (1904)

(2) Kohmen, E. B., Ind. Ing. Chem. Ind. Ed. 14, $527(1922)$

(3) Lewis, W. K. And Robinson, C. S., Ind. Eng. Chem. Ind. Ed. 14, 481 (1922)

(4) Baker, E. K. And Pettibone, E. B., Ind. Fing. Chem. Ind. Ed. 21, 562 (1929)

(5) Lee, C. A., Chem. And Met. Bng., 43, 372 (1936) ibid. pp. 443

(6) Badger And Ifocabe, Wiglemente of Chemical Ingineering," Iot. Ed., pp. 367 - 373 Hew York, McGraw Hill Book Co., 1936

(7) Walker, Lewi, Moldams, And Glliland, "Principles of Chemical Engineering," 3rd Ed., pp. 537 - 543 Hew York, HeGraw - Hill Book Co. 1937

(8) Perry, J.H., "Chemical Engineers' Handbook" and HA. pp. 1382 - 1396, Hew York, HoGraw - Hill Book Co. 1941

(9) Williams, G. C., University of Lonistille, Personal Communi eation

(10) Iange, I. A., "Handbook of Chemistry," 3rd Ed. pp. 1187 - 1188, 1214, Sandusky, On10, Fandbook Publikhers Inc. 1939

(II) "International Critical Tables," Volume III Ist. Ed. pp. 179, Hew York, MoGraw - Hill Book Co. 1928 
VI T 
Howard D. Carlson, oon of Mr. Harry D. Carlson and Irs. Gertrude Foose Carlson, was born June 13, 1921 in the Town of Colonie, Al beny County, New York.

He attended elementery schools in the Town of CoIonie and graduated from Cohoes High School at Cohoes, 11. Y. with a College Intrance Diploma.

He attended Rensselaer Polytechnic Inatitute at Troy, I. Y. and receired a Bachelor of Chemical Ingfneering Degree on Nay 18th, 1942. His theais, "in Inrestigation of Film Coefficients For Condensing Mixed Vapors In The system, Fthanol - Water," was performed under the direction of Dr. I. S. Coonley.

Attending the University of Louistille, he obtained the degree of Master of Chemical Engineering in 1946. His thesis, "A Graphical Solution for Batch stean Distillation of a Binary Hixture, " was performed under the direction of Dr. G. C. Williams.

In Yay 1942 he was employed by F. I. Du Pont de Hemours and Company as Chemical Engineer and asmigned to the production of Neoprene (a synthetic rubber). In April 2945 he mas transferred as a supervisor to a Rocket Powder Plant in Charlestown, Indiana. At the end of the war he was transferred to the Planning Divigion of the Engineering Depertment a Process Engineer, and is now ployed in that section. 